\title{
Taxonomy of the genera Scaeva, Simosyrphus and Ischiodon (Diptera: Syrphidae): Descriptions of immature stages and status of taxa
}

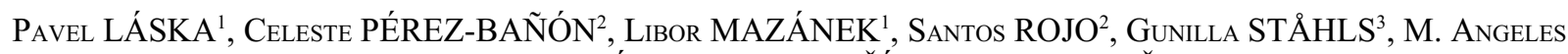 \\ MARCOS-GARCÍA ${ }^{2}$, VítĚZSLAV BIČÍI ${ }^{1}$ and JINDRA DUŠEK ${ }^{4}$
}

\author{
${ }^{1}$ Department of Zoology, Natural Sciences Faculty, Palacký University, Tř. Svobody 26, 77146 Olomouc, Czech Republic; \\ e-mails: mazanek@prfnw.upol.cz, flagell@prfnw.upol.cz \\ ${ }^{2}$ Instituto Universitario de la Biodiversidad (CIBIO), Universidad de Alicante, E-03080 Alicante, Spain; e-mail: celeste.perez@ua. es \\ ${ }^{3}$ Finnish Museum of Natural History, P.O. Box. 17, FIN-00014 University of Helsinki, Finland; e-mail: gunilla.stahls@helsinki.fi \\ ${ }^{4}$ Institute of Applied Entomology, University of Agriculture, Zemědělská 1, 61300 Brno, Czech Republic
}

Key words. Diptera, Syrphidae, Scaeva, Semiscaeva, Mecoscaeva, Simosyrphus, Ischiodon, taxonomy, immature morphology, chaetotaxy, new combination, new synonymy

\begin{abstract}
A review of all known descriptions of immature stages of the species of the genera Scaeva Fabricius, 1805, Ischiodon Sack, 1913 and Simosyrphus Bigot, 1882 is presented using SEM illustrations. The third instar larval and/or pupal morphology of Scaeva dignota (Rondani, 1857), Scaeva mecogramma (Bigot, 1860) and Simosyrphus grandicornis (Macquart, 1842) are newly described. All species of the genera studied in this paper are very similar for all the studied characters of their immature stages, including the chaetotaxy. Molecular characters of the mitochondrial coxl gene (1128bp) were used for inferring relationships of the studied taxa. The nuclear internal transcribed spacer 2 (ITS2) was additionally applied for species delimitation of the closely related species Scaeva selenitica and S. dignota. The Palaearctic Scaeva species could be split into two groups based on the analysis of morphology of posterior respiratory process. These groups were previously diagnosed as $S$. selenitica-group [i.e., S. selenitica (Meigen, 1822), S. dignota (Rondani, 1857), S. mecogramma (Bigot, 1860)] and S. pyrastri-group [i.e., S. pyrastri (Linnaeus, 1758), S. albomaculata (Macquart, 1842), S. latimaculata (Brunetti, 1923)]. Semiscaeva Kuznetzov, 1985 and Scaeva Fabricius, 1805 are the available names for these two natural groups that should be classified as subgenera; the former name is proposed for $S$. seleniticagroup and the latter for S. pyrastri-group. Mecoscaeva Kuznetzov, 1985 syn. n. is transferred as a junior synonym of the subgenus Semiscaeva Kuznetzov, 1985 according to the principle of the first reviser. Based on the analysis of immature stages, the generic name Ischiodon Sack, 1913 syn. n. is proposed as a junior synonym of the genus Simosyrphus Bigot, 1882. The similarity of immature stages between Scaeva s. str. and Simosyrphus grandicornis Macquart, 1842, Simosyrphus aegyptius (Wiedemann, 1830) comb. n. and Simosyrphus scutellaris (Fabricius, 1805) comb. n. is discussed. All the proposed subgeneric and generic taxa based on morphological studies received high support employing molecular characters.
\end{abstract}

\section{INTRODUCTION}

One of the major larval feeding modes of syrphids is predation. The $1800+$ species of Syrphinae make up a large proportion of the species richness of hoverflies, about $35 \%$ of the family. Virtually all of them feed as larvae on soft-bodied Hemiptera (sensu Sörensen et al., 1995) although some species also attack other arthropods (see Rojo et al., 2003). The species of genera Scaeva Fabricius, 1805, Ischiodon Sack, 1913 and Simosyrphus Bigot, 1882 are predatory syrphids with an important role in the bio-control of aphid pest in different areas of the world (e.g. Lal \& Haque, 1965; Schmutterer, 1972; Mukhitdinov, 1985; Singh \& Mishra, 1988; Sharma \& Bhalla, 1991; Xiong \& Dong, 1991; Ekukole \& Ajayi, 1995; Soleyman-Nezhadiyan \& Laughlin, 1998). Descriptions of immature stages of Syrphini are useful for ecological studies, e.g. as a method for comparing the role of various natural enemies of aphids (Láska, 1984) or the study of species relationships, where they provide additional useful characters for phylogenetic studies, which presently are based mainly on characters of adults.
In 1985 two revisions of the genus Scaeva were published independently by Dušek \& Láska (1985) and Kuznetzov (1985). However, these two revisions are quite different in species conceptions and in subgeneric classification. Recent authors usually follow the concept of Dušek \& Láska (e.g. Speight, 2003), but up to now no nomenclatorical acts have been published to clarify this situation. The defence of Dušek \& Láska's concept (1985) is also part of our contribution with the use of newly available data obtained for this study.

According to Kassebeer (1999) and Thompson (2003), 19 valid names of the genus Scaeva exist at present. These species of Scaeva are mainly distributed in the Palaearctic (with two species reaching the Oriental region and one species the Nearctic region) and Neotropical (four species) regions. The genus Ischiodon comprises three species only (one endemic of the Cape Verde Islands, one mainly present in Africa and one in the Oriental-Austral region), and of the genus Simosyrphus (exclusive to the Australian region, including Pacific) only one species is known. These three genera - Scaeva, Ischiodon, Simosyrphus Dušek \& Láska (1985) ranged into Scaeva group. 
The single species of Simosyrphus bears a strong resemblance to the species of Ischiodon, with which it has often been confused (e.g. Bryan, 1934). In his famous world revision of the genera of the Syrphini, Vockeroth (1969) was at first inclined to refer all the species of the genera Ischiodon and Simosyrphus to a single genus despite the apparent differences in the male terminalia. He finally concluded that both genera are related but not congeneric. This author also discussed the close relationship between Scaeva and Eupeodes Osten Sacken, 1877 (including Metasyrphus Matsumura, 1917) but did not support a relation between Scaeva and Simosyrphus. Dušek \& Láska (1985) first diagnosed these taxa including Ischiodon and Simosyrphus as a natural group, using both larval and adult morphology. Monophyly of the genera Scaeva, Eupeodes and Ischiodon was recovered in the parsimony analysis of Palaearctic Syrphidae larvae (Rotheray \& Gilbert, 1999), but the larvae of the genus Simosyrphus and some Scaeva species of the Mediterranean and Oriental regions were undescribed and thus not included. In the present work we redescribe or describe the third instar larvae and/or puparia of the species of Scaeva, Ischiodon and Simosyrphus and give a key to known immature stages of the species.

Additionally, in the present study we use DNA sequences of two genes, the mitochondrial cytochrome $\mathrm{c}$ oxidase subunit I (hereafter $\operatorname{cox} 1$ ), and the nuclear ribosomal internal transcribed spacer two (ITS2) for understanding the species limits of very closely related taxa. The mitochondrial cox 1 has been used and proven to be valuable for inferring species-level phylogenies of other syrphid genera (Ståhls \& Nyblom, 2000; Pérez-Bañón et al., 2003), as well as for other insects (e.g. Caterino \& Sperling, 1999). Recent findings, however, indicate that the cox 1 might be too slowly evolving to be informative between very closely related species (recent speciation), as interspecific divergences are close to zero (Milankov et al., 2005; Rojo et al., 2006; G. Ståhls, unpubl. data). Hebert et al. (2003), and Megens et al. (2004) showed that pairwise uncorrected divergence values for coxl were generally greater than 3\% between species of Lepidoptera in general. Both studies also report genetically distinct but very low divergences of the cox $1(0.6-2.4 \%)$ for congeneric species pairs, suggesting these low values as indicative of very recent origins of species. The nuclear non-coding ITS2 is a rapidly evolving region and has proved useful for comparing closely related insect species, subspecies or populations in insects (e.g. Álvarez \& Hoy, 2002), indicating that the mutation rate could ordinarily be higher for the ITS2 than for any mitochondrial (protein coding) gene. We explored the utility of both gene regions for the specific study of the closely related species pair Scaeva dignota (Rondani, 1857) and S. selenitica (Meigen, 1822), and to use the coxl for inferring the phylogenetic relationships among the taxa of this study using seven representatives.

Proposed taxonomical changes are mainly based on the study of immature morphology, but we also find the molecular characters highly informative to address these questions. Genotypes can be expected to express variation for recently diverged species even when morphological characters still show no variation or it is difficult to observe. The adult morphologies are discussed in relation to results obtained using the two above mentioned character sets. The final conclusions as well as proposed taxonomical changes, however, are established in light of all character sets and long term study of Syrphini. The discussion deals also with some paradoxes in relation to evolution of larval and adult characters.

\section{MATERIAL AND METHODS}

\section{Morphological studies}

We have used numerous larvae and puparia of the Scaeva species and several puparia of the Simosyrphus and Ischiodon species stored in the entomological collection of the Universidad de Alicante, Alicante, Spain (CEUA) and Department of Zoology and Anthropology, Olomouc, Czech Republic (UP).

Third instar larvae and empty puparia were studied. Larvae were either reared in laboratory from eggs or were obtained by searching in the field. Collected gravid females (see UP material) were put in separated boxes with a plantlet of Vicia faba (Fabaceae) previously infested with the pea aphid Acyrthosiphon pisum (Harris, 1776) (Hemiptera: Aphidoidea). The methodology for laboratory breeding of the aphids was adopted from Department of Entomology at the Academy of Sciences of the Czech Republic (České Budějovice). Syrphid field-collected larvae were usually fed with aphids from the same colony where they were collected. Rearing took place in a growth chamber at $16-22^{\circ} \mathrm{C}, 80 \pm 5 \% \mathrm{RH}$ with a constant photo regime of $15 \mathrm{~L}: 9 \mathrm{D}$ (CEUA material) or at $22-25^{\circ} \mathrm{C}$ with $16 \mathrm{~L}: 8 \mathrm{D}$ (UP material). Puparia were isolated in individual Petri dishes and inspected daily until the adults emerged.

Third instar larvae were selected for preservation after the hindgut was emptied. Obtained larvae were fixed by immersion in boiling water and boiling gently for about four minutes to extend them; they were preserved in $70 \%$ alcohol afterwards and part of the obtained larvae were lyophilised. To study the prothorax, mesothorax and metathorax morphology, we extended these parts by lightly pressing the first abdominal segments.

Descriptions are based on preserved larvae and/or puparia. Larval characters were checked against living specimens, when possible. Dimensions were measured on preserved material using a binocular microscope (Leica Wild M8) with an eyepiece micrometer and illustration made with a drawing tube. The width of the posterior respiratory process (below PRP) was measured from anterolateral points of carinae I in posterodorsal view (see Fig. 6).

Terminology used for descriptions of larvae and pupae follows Dušek \& Láska (1964). The term orificium (Vimmer, 1925) was used instead of spiracular slits, and the term periorificial ornamentation was used instead of interspiracular ornamentation that is used in papers by other authors, following Bhatia's (1939) fundamental work on morphology and anatomy of aphidophagous syrphid larvae. The positions of the sensillae were numbered from the dorsal to the ventral surface of each segment (see Fig. 4), as decribed by Rotheray (1991).

\section{Molecular studies}

DNA was extracted usually from legs (of a single individual) of frozen specimens or from specimens preserved in $70-95 \%$ alcohol (Table 1). Adults were conserved as DNA voucher specimens. DNA was extracted using the Nucleospin Tissue Kit 
TABLE 1. List of specimens used for DNA analysis. X denotes obtained sequence not submitted for GenBank.

\begin{tabular}{|c|c|c|c|c|c|}
\hline & Genus Scaeva, subgenus Semiscaeva & & & Coxl & ITS2 \\
\hline S100 & Scaeva dignota (Rondani) & Greece, Lesbos island, iv.2001, leg. S. Rojo \& C. Pérez & CIBIO & $\mathrm{X}$ & $\mathrm{X}$ \\
\hline S107 & Scaeva dignota (Rondani) & Greece, Lesbos island, iv.2001, leg. S. Rojo \& C. Pérez & CIBIO & AY603766 & $\mathrm{X}$ \\
\hline S135 & Scaeva dignota (Rondani) & Italy, South Tirol, Val Venosta, vii.2001, leg. G. Ståhls & ZMH & $\mathrm{X}$ & DQ158893 \\
\hline S195 & Scaeva dignota (Rondani) & Greece, Lesbos island, iv.2001, leg. S. Rojo \& C. Pérez & CIBIO & $\mathrm{X}$ & $\mathrm{X}$ \\
\hline S196 & Scaeva dignota (Rondani) & Greece, Lesbos island, iv.2001, leg. S. Rojo \& C. Pérez & CIBIO & & DQ158894 \\
\hline S198 & Scaeva dignota (Rondani) & Spain, Alicante, 17.vi.2001, leg. S. Rojo \& C. Pérez & CIBIO & $\mathrm{X}$ & $\mathrm{X}$ \\
\hline S199 & Scaeva dignota (Rondani) & Spain, Alicante, 26.vi.2001, leg. S. Rojo \& C. Pérez & CIBIO & $\mathrm{X}$ & \\
\hline S66 & Scaeva selenitica (Meigen) & $\begin{array}{c}\text { Czech Republic, distr. Chomutov, Lestkov, 21.iv.2000, } \\
\text { leg. L. Mazánek }\end{array}$ & CIBIO & $\mathrm{X}$ & $\mathrm{X}$ \\
\hline S69 & Scaeva selenitica (Meigen) & $\begin{array}{c}\text { Czech Republic, distr. Ostrava, Polanecký les, 3.iv.2000, } \\
\text { leg. T. Kuras }\end{array}$ & , CIBIO & 603764 & $\mathrm{X}$ \\
\hline S126 & Scaeva selenitica (Meigen) & Italy, South Tirol, Val Venosta, vii.2001, leg. G. Ståhls & ZMH & $\mathrm{X}$ & $\mathrm{X}$ \\
\hline S127 & Scaeva selenitica (Meigen) & Italy, South Tirol, Val Venosta, vii.2001, leg. G. Ståhls & $\mathrm{ZMH}$ & $\mathrm{X}$ & DQ158895 \\
\hline \multirow[t]{2}{*}{$\mathrm{S} 134$} & Scaeva selenitica (Meigen) & Italy, South Tirol, Val Venosta, vii.2001, leg. G. Ståhls & ZMH & $\mathrm{X}$ & DQ158896 \\
\hline & \multicolumn{4}{|l|}{ Subgenus Scaeva s. str. } & \\
\hline $\begin{array}{l}\text { S105 } \\
\end{array}$ & Scaeva albomaculata (Macquart) & \multicolumn{4}{|c|}{ Greece, Lesbos island, iv.2001, leg. S. Rojo \& C. Pérez CIBIO AY603765 } \\
\hline \multirow[t]{2}{*}{ S97 } & Scaeva pyrastri (Linnaeus) & \multicolumn{4}{|c|}{ Greece, Lesbos island, iv.2001, leg. S. Rojo \& C. Pérez CIBIO AY603767 } \\
\hline & Genus Simosyrphus & & & & \\
\hline S288 & Simosyrphus grandicornis Macquart & Australia, Brisbane, 5.x. 2002, leg. H. Hippa & \multicolumn{3}{|c|}{ ZMH AY603770 } \\
\hline S157 & Simosyrphus (=Ischiodon) scutellaris Fabricius & Hong-Kong, 7.x.2001, leg. D. Iliff & \multicolumn{3}{|c|}{ ZMH AY603768 } \\
\hline S361 & Simosyrphus (=Ischiodon) aegyptius Wiedemann & Morocco, Guelmim, 28.xii.2002, leg. J.-H. Stuke & \multicolumn{3}{|c|}{ ZMH AY603769 } \\
\hline \multicolumn{2}{|c|}{ Outgroup Eupeodes (Lapposyrphus) lapponicus (Zetterstedt) } & Czech Republic, 13.v.2000, leg. L. Mazánek & ZMH & Q158897 & \\
\hline
\end{tabular}

(Machery-Nagel, Düren, Germany) according to manufacturer's protocols, and resuspended in $50 \mu 1$ of ultra-pure water.

PCR's were carried out in $25 \mu 1$ reactions containing 1-2 $\mu 1$ DNA extract, $1 \mu 1$ of each primer (at $10 \mathrm{pmol} / \mathrm{ml}$ ), $0.25 \mu 1$ of Amplitaq DNA polymerase (5U/ $\mu \mathrm{l}), 2 \mu \mathrm{l} 2.5 \mathrm{mM} \mathrm{MgCl}, 2.5 \mu \mathrm{l}$ 10X Buffer II (Applied Biosystems, Foster City, CA, USA) and $4 \mu 1200$ mM dNTP (GeneAmp, Applied Biosystems) and water. Thermocycler conditions were initial denaturing at $95^{\circ} \mathrm{C} 2 \mathrm{~min}$, 29 cycles of $30 \mathrm{~s}$ denaturing at $94^{\circ} \mathrm{C}, 30 \mathrm{~s}$ annealing at $49^{\circ} \mathrm{C}, 2$ min extension at $72^{\circ} \mathrm{C}$, followed by a final extension of $8 \mathrm{~min}$ at $72^{\circ} \mathrm{C}$. PCR products were purified using the GFX PCR Purification Kit (Amersham Biotech, Little Chalfont, UK) and then sequenced (using the same PCR primers) in both directions using the Big Dye Terminator Cycle Sequencing Kit (Applied Biosystems) at one-fourth of the recommended volumes on ABI PRISM 377 and ABI 310 automated DNA sequencers. The primers used for amplifying and sequencing the $\operatorname{cox} 1$ and ITS2 fragments are listed in Table 2. Sequences were edited and assembled using Sequence Navigator ${ }^{\mathrm{TM}}$ (version 1.01, Applied Biosystems). We produced nucleotide sequences of the cox 1 and ITS2 genes of several specimens of the closely related species Scaeva dignota and $S$. selenitica, in addition to other species of the genus Scaeva (see Table 1).

We used the obtained sequence data to calculate uncorrected pairwise coxl sequence divergences for $S$. dignota and $S$. selenitica. We determined the ITS2 sequences of six specimens of $S$. dignota and five specimens of $S$. selenitica (Table 1), and these were manually aligned to identify sequence variation for these taxa.

We performed a parsimony analysis using one coxl sequence to represent each taxon included in this study and using equal weights with the computer program Nona version 2.0 (Goloboff, 1993) to study the relationships of species-groups in Scaeva, and the relationships among Scaeva, Ischiodon and Simosyrphus. Bremer support values (Bremer, 1994) were calculated using Nona by successively increasing the number of trees retained (hold 1000; suboptimal 1; find*: followed by hold 2000; suboptimal 3; find*: etc.), to avoid overestimating the values. Bootstrap values were calculated using Winclada (Nixon, 2002) with 1000 pseudoreplicates. Eupeodes (Lapposyrphus) lapponicus (Zetterstedt, 1838) was used as outgroup.

\section{TAXONOMIC ACTIONS}

On the basis of new data provided by this study and long term study of Syrphini we propose in this paper the following arrangement of taxa.

\section{Scaeva Fabricius, 1805}

Palaearctic Scaeva species can be clearly split into two groups based mainly on the morphology of PRP. The first group corresponds to the S. selenitica-group of Dušek \& Láska (1985), and second group to the S. pyrastri-group

TABLE 2. Primers used for amplifying and sequencing the cox 1 and ITS2 fragments.

\begin{tabular}{lll}
\hline Primer & Sequence & Source \\
\hline TL2-N-3014 & 5'-TCCAATGCACTAATCTGCCATATTA-3' & Simon et al., 1994 \\
C1-S-1718 & 5'-GGAGGATTTGGAATTGATTAGTTCC-3' & Simon et al., 1994 \\
C1-J-2183 & 5'-CAACATTTATTTTGATTTTTTGG-3' & Simon et al., 1994 \\
ITS2A (f) & 5'-TGTGAACTGCAGGACACAT-3' & Beebe \& Saul, 1995 \\
ITS2B (r) & 5'-TATGCTTAAATTCAGGGGGT-3' & Beebe \& Saul, 1995 \\
\hline
\end{tabular}



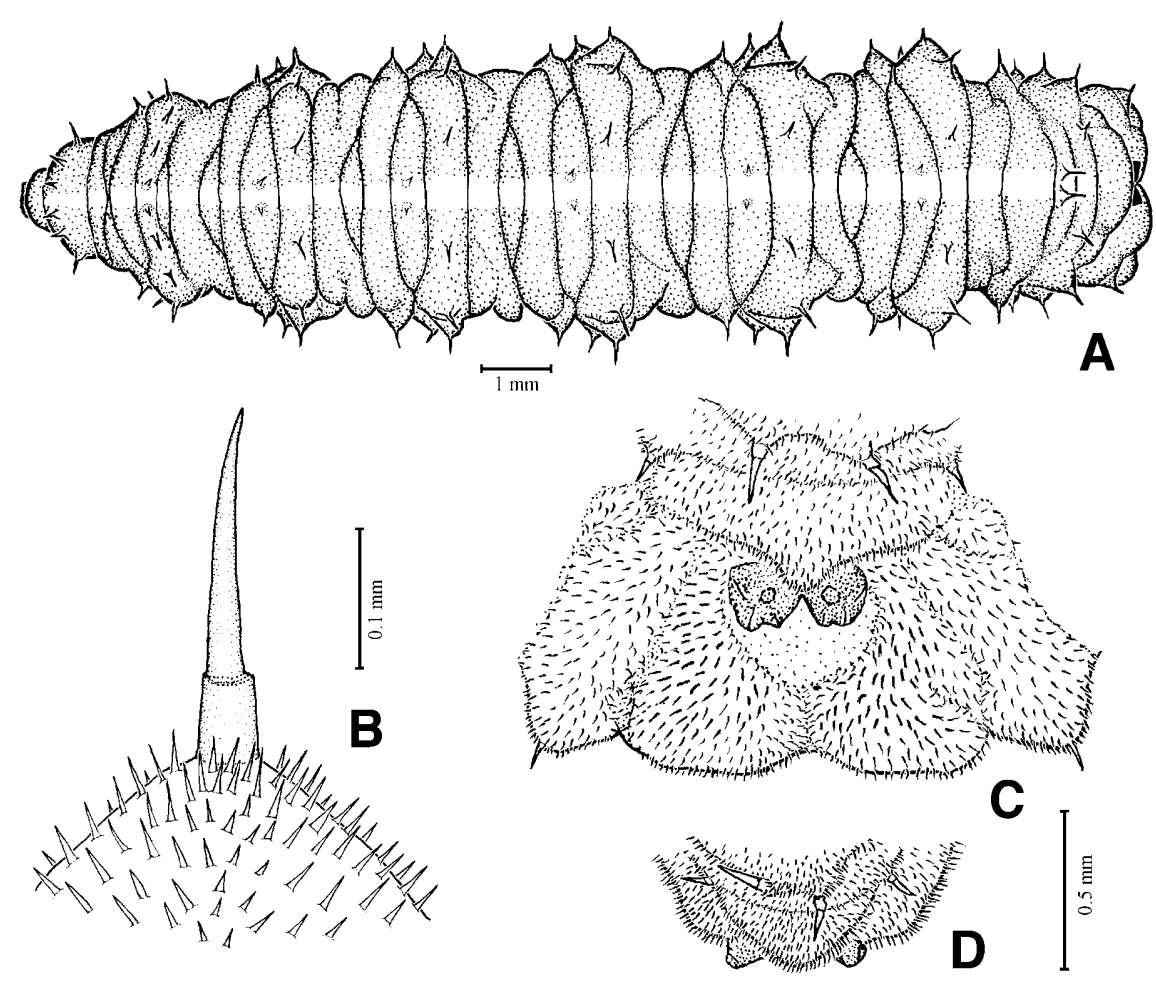

Fig. 1. A, B: Third instar larva of Scaeva selenitica. A - dorsal habitus; B - segmental spine $2^{\mathrm{A} 6}$ with its fleshy projection. C, D: Scaeva albomaculata. C - posterior end of the third instar larva; D - posterior end of puparium.

of Dušek \& Láska (1985). These alleged natural groups were diagnosed by Dušek \& Láska (1985: p. 226) using both adult and larval characters. We propose to classify them as subgenera. For genesis of proposed subgeneric names see discussion.

\section{Subgenus Semiscaeva Kuznetzov, 1985}

[= S. selenitica group sensu Dušek \& Láska (1985: 226)]

Semiscaeva Kuznetzov, 1985: 412 (as subgenus of Scaeva Fabricius, 1805). Type species Catabomba odessana Paramonov, 1924 (orig. des.) = S. dignota (Rondani, 1857).

Mecoscaeva Kuznetzov, 1985: 418 (as subgenus of Scaeva Fabricius, 1805). Type species Lasiophthicus mecogramma Bigot, 1860 (monotypy). Syn. n. (first reviser).

\section{Subgenus Scaeva s. str.}

[= S. pyrastri group sensu Dušek \& Láska (1985)]

Scaeva Fabricius, 1805: 248. Type species: Musca pyrastri Linnaeus, 1758 (des. Curtis, 1834: pl. 509).

\section{Synonymy of Simosyrphus Bigot, 1882 and Ischiodon Sack, 1913}

Vockeroth (1969) provided differential diagnosis and detailed descriptions of adult characters of both genera. The new data of this paper, larval and pupal morphology and molecular data confirm the very close relationship of Simosyrphus and Ischiodon. We propose their synonymy and a sister-group relationship with the genus Scaeva.

\section{Simosyrphus Bigot, 1882}

Simosyrphus Bigot, 1882: 68. Type species Syrphus grandicornis Macquart, 1842 (sub. des. Hull, 1949: 291).
Ischiodon Sack, 1913: 6. Type species: Ischiodon trochanterica Sack, 1913 (monotypy) = I. scutellaris (Fabricius, 1805). Syn. n.

\section{DESCRIPTION OF IMMATURE STAGES}

\section{Scaeva Fabricius, 1805}

Third instar larva

Length 12-18 mm, maximum width 3.0-4.0 $\mathrm{mm}$. Overall appearance: Oval in cross-section with a little flattened ventral surface, tapering anteriorly and slightly truncate posteriorly. Dorsal habitus wrinkled (Fig. 1A), slightly serrate owing to fleshy projections with segmental spines (sensillae with setae). Colour pattern variable in ground colour even at intraspecific level (green, brown or pink) with a median dorsal white, cream or pink stripe. Prothorax and mesothorax normally retracted into metathorax. Boundaries between segments obscured by secondary grooves and folds in integument (Fig. 1A). Abdominal segments usually bearing five secondary folds. The pattern of segmental spines is very useful for orientation in primary segmentation, mainly the position of the segmental spines of each side of abdominal segments. Pairs 1 and 2 of segmental spines both located on second fold in metathorax and first abdominal segment; in other abdominal segments, pair 2 of segmental spines located just on the next fold (Fig. 1A). Segmental spines not pigmented, fully developed (0.15-0.28 mm long), with wide base (about 1/3 length of spine) and a narrow apical part (Fig. 1B). Integumental vestiture distinct in most species, of cuticle colour or brown pigmented, smaller in groves and on ventral surface. Dorsal body sur- 

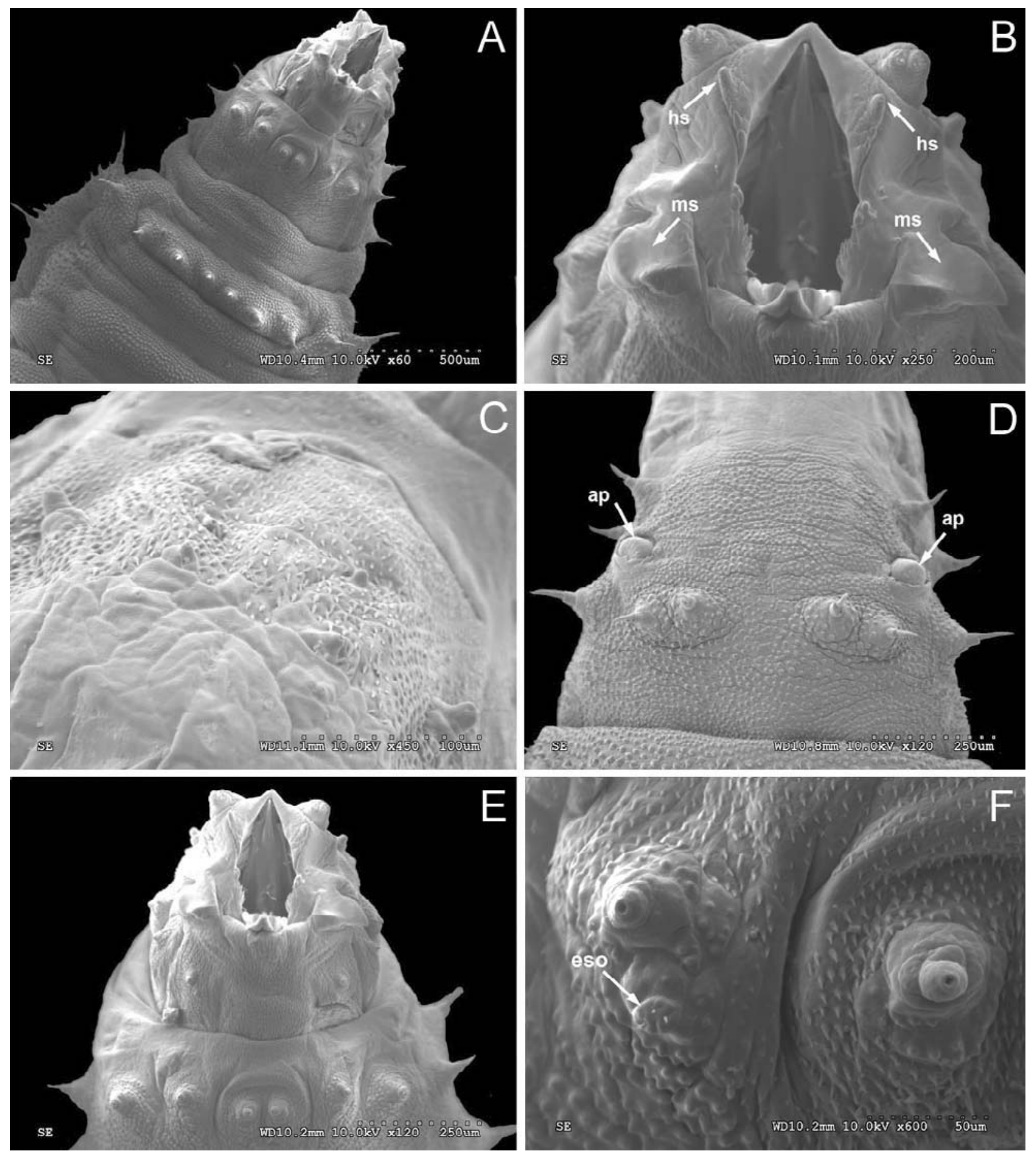

Fig. 2. Third instar larva of Scaeva dignota. A - head and thorax, ventral view; B - head, anteroventral view (ms - prothoracic sclerites, hs - head sensilla); C - dorsal surface of prothorax; D - mesothorax, dorsal view (ap - anterior respiratory process); E prothorax and mesothorax, ventral view; F - detail of the extra pair of sensory-organ (eso) near sensillae $7^{\mathrm{Ms}}$, ventral view.

face covered with elongated microtrichia or rarely coated with short pointed, almost triangular spicules. PRP very short, only $0.15-0.25 \mathrm{~mm}$ long, without peritrema and normally recessed in a fleshy depression.

Head. Head very reduced (Fig. 2A). Mouthparts adapted for piercing-feeding (Hartley, 1963) with distinctive features of predacious syrphid larvae. Lateral margins of mouth with pair of black triangular pointed sclerites (Figs 2B, 3A). Antenno-maxillary organs well- developed (Fig. 2B). One pair of sensilla located above mouth and below antenno-maxillary organs (Fig. 2B).

Thorax. Prothorax with eleven pairs of sensillae hardly visible by light stereomicroscopy (Figs 2C, 4). Dorsal surface of prothorax with anterior respiratory process sclerotised and short, with semicircular openings on its anterior margin (Fig. 2D). Vestiture of prothorax above sensilla $4^{\mathrm{P}}$ reduced, giving the integument a clear shining appearance (Fig. 2C). Anterior fold of prothorax with 

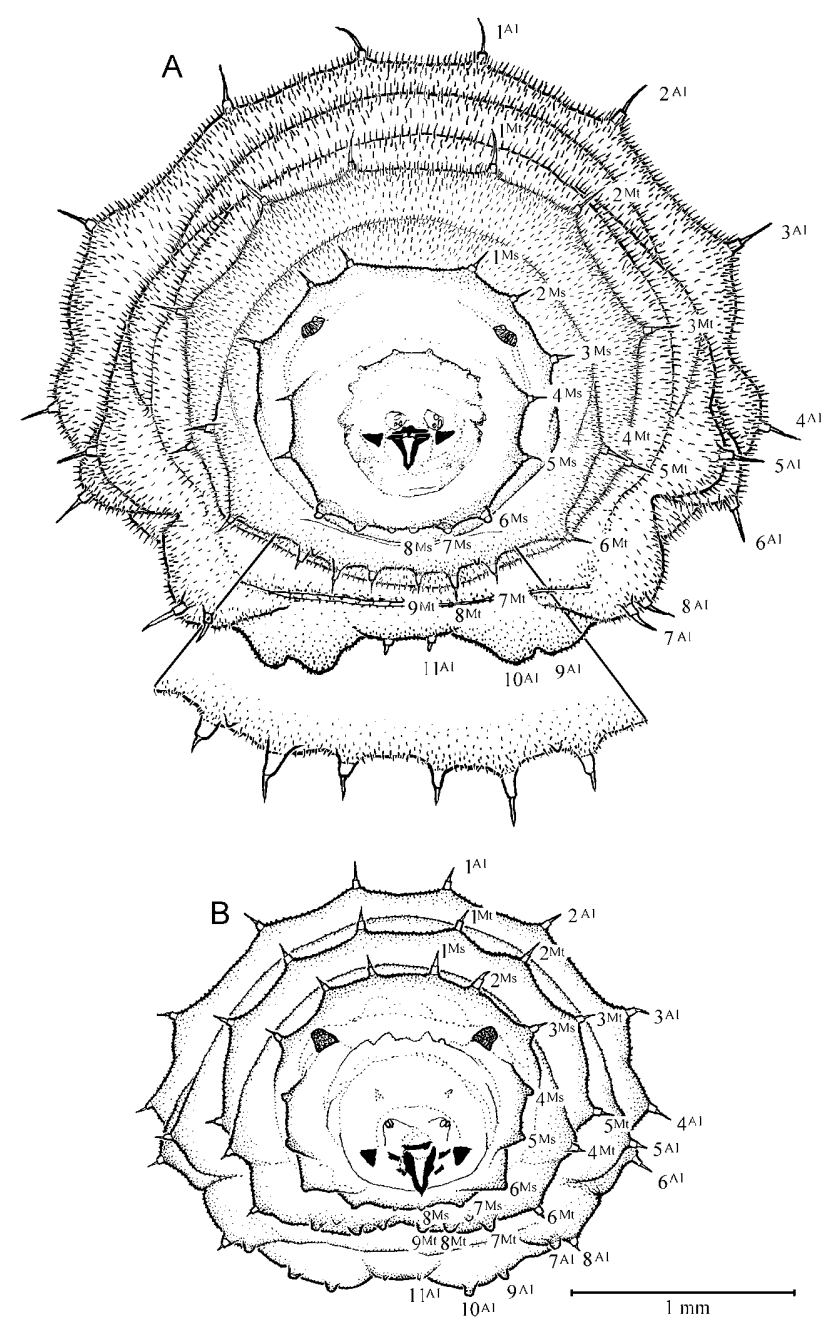

Fig. 3. Thoracic and first abdominal segments of the third instar larva, anterior view. A - Scaeva selenitica with two times magnified arrangement of $7^{\mathrm{Mt}}-9^{\mathrm{Mt}}$ segmental spines; B - Syrphus ribesii.

longitudinal grooves and a ring (extending $<35 \%$ of dorsal surface and $<60 \%$ of ventral surface) of small, backwardly directed spicules which become progressively densely-aggregated posteriorly on dorsal surface (Fig. 2C). Mesothorax with eight pairs of sensillae arranged in two main transverse rows: dorsal row with short segmental spines $1-3$ and ventral row located slightly anteriorly bearing five pairs of sensillae, two pairs of dorso-lateral segmental spines followed by three pairs of ventral papiliform sensillae (Figs 2E, 3A, 4). Metathorax with nine pairs of sensillae arranged in two main transversal rows: dorsal row with four pairs of segmental spines and ventral row located slightly anteriorly with five pairs of segmental spines of unequal length; setae on sensillae $7^{\mathrm{Mt}}$ and $9^{\mathrm{Mt}}$ shorter than others (Figs 3A, 5A, 4). Contrary to e.g. Syrphus Fabricius, 1775, Megasyrphus Dušek et Láska, 1967 bearing on metathorax ventrally only papilliform sensillae (Fig. 3B). One extra pair of sensory-organs near sensillae $7^{\mathrm{Ms}}$ and $7^{\mathrm{Mt}}$ (hardly visible by light stereomicroscope) (Figs 2F, 5A).
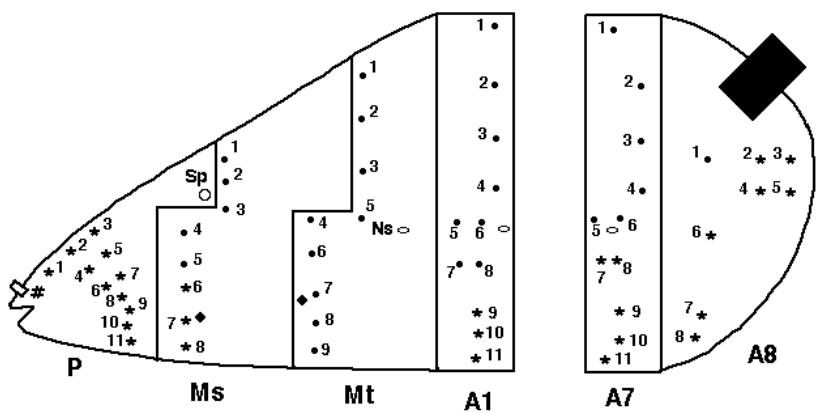

Fig. 4. Map of the chaetotaxy of the third instar larva of the Scaeva species showing the positions of the groups of sensillae: P - prothorax; Ms - mesothorax; Mt - metathorax; A1, A7 first and seventh abdominal segments; A8 - eighth abdominal segment with PRP; Sp - anterior respiratory process; Ns - nonfunctional spiracle. Symbols: \# - head sensillae; • - segmental spines; * - segmental sensillae without setae; - extra pair of sensory organs.

Abdomen. Abdominal segments with eleven pairs of sensillae (Figs 3A, 4). First abdominal segment with three pairs of papiliform sensillae ventrally (Fig. 5B) and eight pairs of segmental spines dorso-laterally (Fig. 3A); pairs of segmental spines $1^{\mathrm{A} 1}$ and $2^{\mathrm{A} 1}$ located on the same fold. Second to seventh abdominal segments with the pair of segmental spines $1^{\mathrm{A} 2-7}$ on second fold and pair of segmental spines $2^{\mathrm{A} 2-7}$ placed on third fold, together with two further pairs of segmental spines. Five ventral pairs of sensillae reduced to papillae. On seventh abdominal segment, pair of segmental spines $1^{\mathrm{A} 7}$ separated from base of PRP by two folds, the posterior distinctly more developed (almost two times or more) and with microtrichia slightly enlarged in medial area. Integumental vestiture of the depression below PRP reduced in small nodules or spicules variable in their shape. On eighth abdominal segment, eight pairs of sensillae (Fig. 4), only first pair with setae (Figs 4, 5C). Locomotory prominences well developed; seven pairs present on abdominal segments 1-7 (Fig. 5B). Locomotory organs in front of anal openings consisting of four lobes each. Tip of anal segment with three pairs of lobes in ventral view (Figs 5C,5D); posterior surface of lobes covered with denselyaggregated spicules, tip of lobes without vestiture (Fig. 5D). Anal papillae short, rudimental as in other Syrphini. One pair of papillae divided in two branches of identical length; length of papilla about $0.5-0.6 \mathrm{~mm}$ including common stem about $0.1-0.2 \mathrm{~mm}$ long, each branch cylindrical about $0.15-0.2 \mathrm{~mm}$ in diameter. PRP: Pale to dark brown in colour, lustrous. Spiracular plate differs at subgeneric level, divided by a V-shape median groove about as deep as half or more the length of PRP, dorsal spur present or absent (see Figs 6B, D). Orificia straight, mounted on well developed carinae extending towards side of PRP. Carinae about two times or more longer than broad. Periorificial ornamentation reduced, periorificial setae very small, hardly visible by light microscope, mounted inside of small circular nodules (Figs 6A, 6C). 

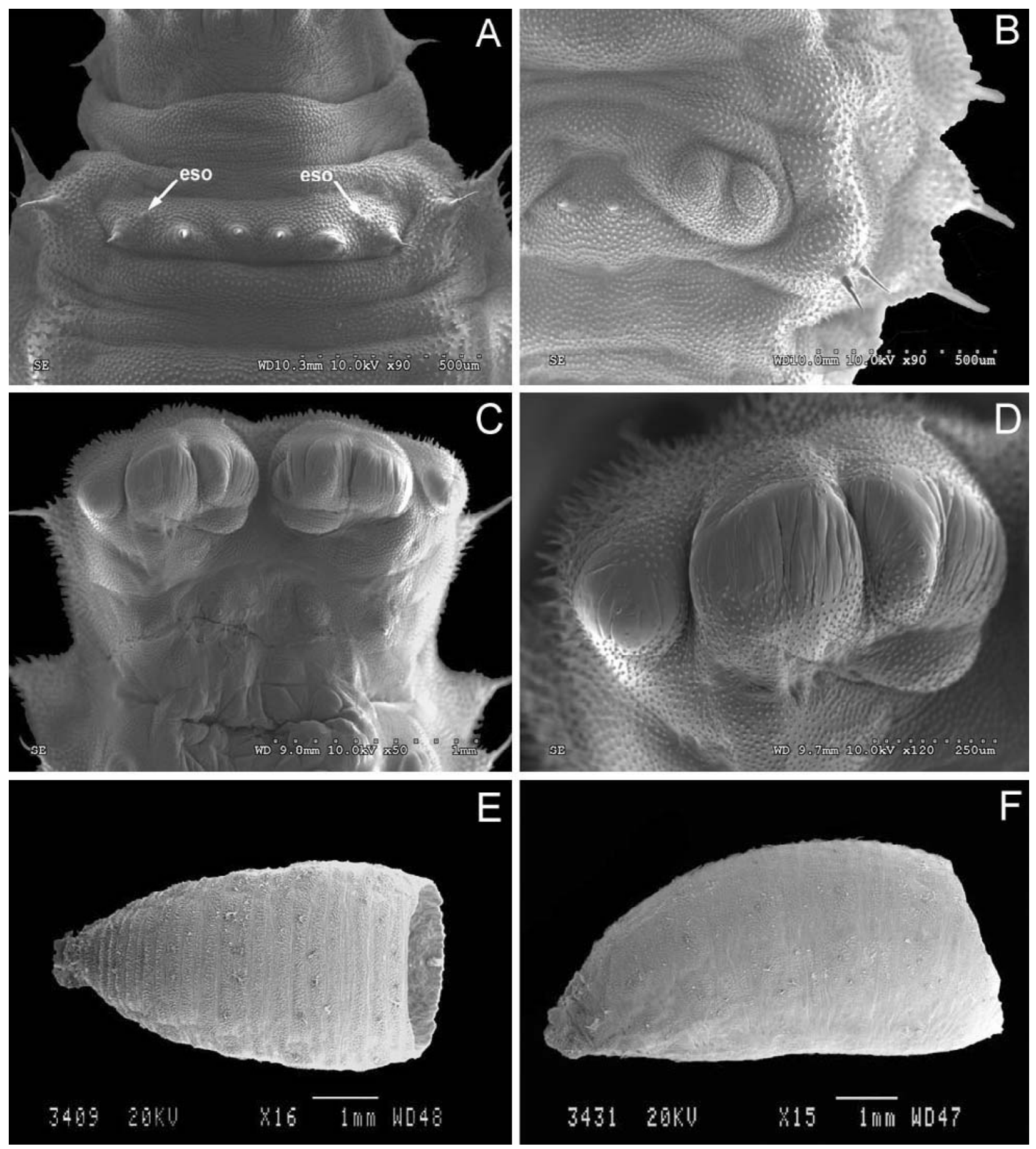

Fig. 5. Scaeva dignota. A - metathorax of third instar larva, detail of ventral chaetotaxy end extra pair of sensory organs (eso) near sensilla $7^{\mathrm{Mt}}$, ventral view; B - locomotory prominences of the first abdominal segment, ventral view; C - anal segment, ventral view; $\mathrm{D}$ - detail of locomotory organ on the tip of anal segment, ventral view; E - puparium, dorsal view; F - puparium, lateral view.

\section{Puparium}

Length 7.5-9 mm, maximum width 3.0-4.0 mm. Rather cask-like than pear-like, sub-cylindrical in cross-section (Fig. 5E). Anterior extreme truncated, slightly tapering posteriorly and flattened ventrally (Fig. 5F). Colour varies from cream to dull brown, sometimes with dark segmental patterns caused by pigmented cuticle. Dark patterns variable even at intraspecific level. Integumental vestiture and segmental spines persisting. Segmental spines of cuticle colour, about the same length as in larvae, but dried rests of fleshy projections bearing segmental spines usually inconspicuous. Sclerotised PRP almost without changes, only carinae black edging (Fig. 6).

\section{Subgenus Semiscaeva Kuznetzov, 1985}

Diagnostic characters. Colour pattern of larva variable in ground colour at intraspecific level (green, brown or pink) with a median dorsal white, cream or pink stripe. 

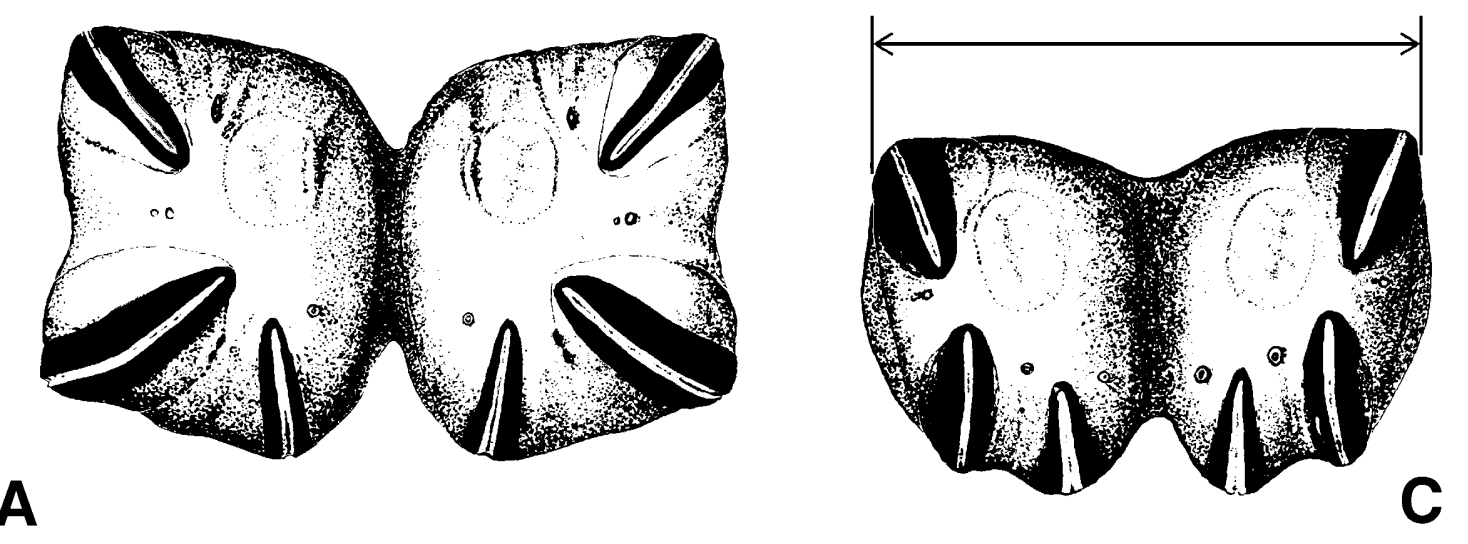

A
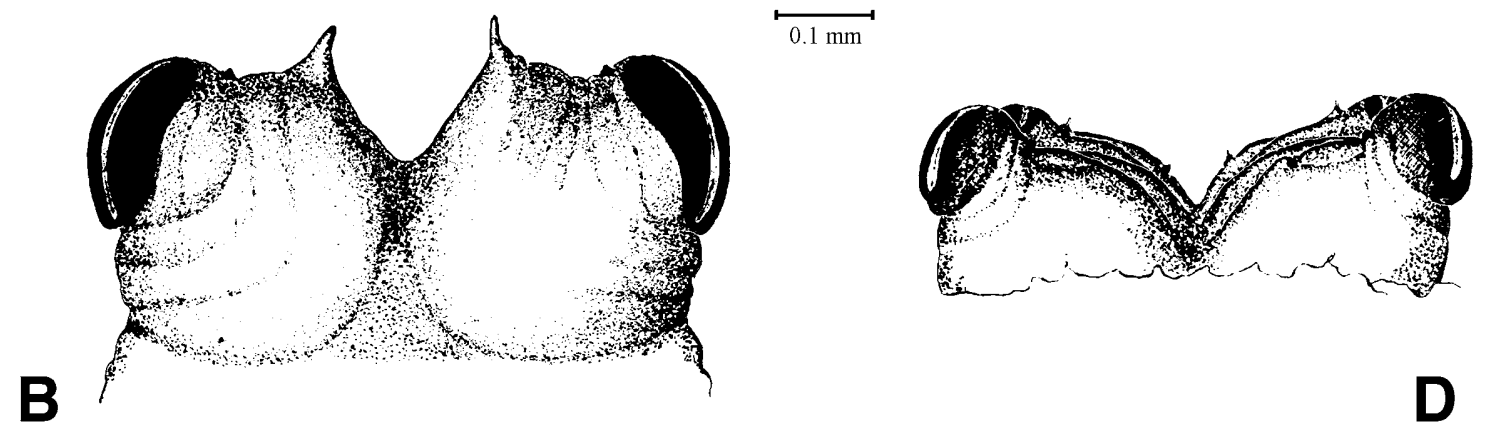

Fig. 6. PRP of puparium of Scaeva spp. (A, C - posterodorsal view; B, D - anterodorsal view). A, B - S. (Semiscaeva) selenitica; $\mathrm{C}, \mathrm{D}-\mathrm{S}$. (Scaeva) pyrastri (measurement of the width of the PRP marked).

Integument coated with distinct, not furcate microtrichia about $0.03-0.07 \mathrm{~mm}$ long on dorsum; posterior folds coated with microtrichia with wide base and narrow tip (Figs 7A, 7C, 7E); integument of depression below PRP covered with smaller, scarcer, pedunculate nodules and spicules (Figs 7B, 7D, 7F). PRP: Short (0.19-0.29 mm long), pale to dark brown in colour. Spiracular plate as high as wide, or a little higher than wide (Fig. 6A). $\mathrm{V}$-shaped median grove about as deep as half the length of PRP (Fig. 6B). Dorsal spur present, short (about $0.02-0.03 \mathrm{~mm}$ long), pointed and continuous with medial border of ecdysial scar (Figs 6A, 6B). Orificia equidistant from each other; angle between orificia I/II and II/III near $90^{\circ}$ (Fig. 6A). Orificia mounted on raised carinae and all extending more than 0.5 of their length down the sides of PRP (Fig. 6B). Carinae I and II a little more developed than carina III.

\section{Scaeva selenitica (Meigen, 1822)}

Immature stages previously described by Scott (1939), Brauns (1953), Dušek \& Láska (1959), Dixon (1960) and Speight et al. (1986, only puparium). Larvae predatory on a wide range of aphids, prey records cited by Rojo et al. (2003, p. 202-204).

Diagnostic characters. The larva can present two patterns of colouration, green with a white median stripe (as in $S$. pyrastri) or brownish similar to Eupeodes spp. larvae. Body surface coated with well developed brown pigmented microtrichia about $0.03-0.045 \mathrm{~mm}$ long on dorsum. Dark segmental pattern on puparium present as dots arranged on dorsum, even if sometimes inconspicuous. Posterior folds coated with microtrichia with a wide base that becomes suddenly fine (Fig. 7A). PRP: (Width: 0.56-0.65 mm, height: $0.30-0.41 \mathrm{~mm}, \mathrm{n}=10$ ). Short, pale brown in colour. Median groove deeper than half the length of PRP, in anterior view tips of dorsal spurs as wide apart as more than semi-diameter of spiracular plate (Figs 8A, 8B). Ecdysial scars displaced towards median groove and anteriorly (Fig. 8A). Carinae I and II well developed with clear depression between them (Fig. 8A). Periorificial setae mounted inside of circular nodules, periorificial setae between orificia I and II close, with their nodules connected (Fig. 8A).

Material examined. Czech Republic. Olomouc - Svatý Kopeček: about 30 puparia, reared from eggs, female 24.viii.1974, leg. P. Láska; Valy u Přelouče: 4 puparia (3 +1 đ $)$ 4 larvae, reared from eggs, female 29.v.1999, leg. L. Mazánek; Ostrava, Polanecký les: 11 puparia $(60,5 \%) 13$ larvae, reared from eggs, female 3.iv.2000, leg. T. Kuras; Lestkov, Distr. Chomutov: 9 puparia, 19 lyophilised larvae, reared from eggs, female 21.iv.2000, leg. L. Mazánek.

Distribution. Palaearctic, subboreal (see also discussion).

\section{Scaeva mecogramma (Bigot, 1860)}

Immature stages described here for the first time. Rojo et al. (1999) studied larval biology and two species of psyllids on olive-trees were cited as prey. Larvae are probably specialised predators of psyllids.

Diagnostic characters. Only green larvae with white medial stripe were observed. Body of larvae and puparia usually totally covered with whitish waxen flakes secreted by psyllids. Microtrichia of cuticle colour, well developed, about 0.04-0.07 mm long on dorsum. Cuticle of puparium without dark patterns. PRP: (Width: 

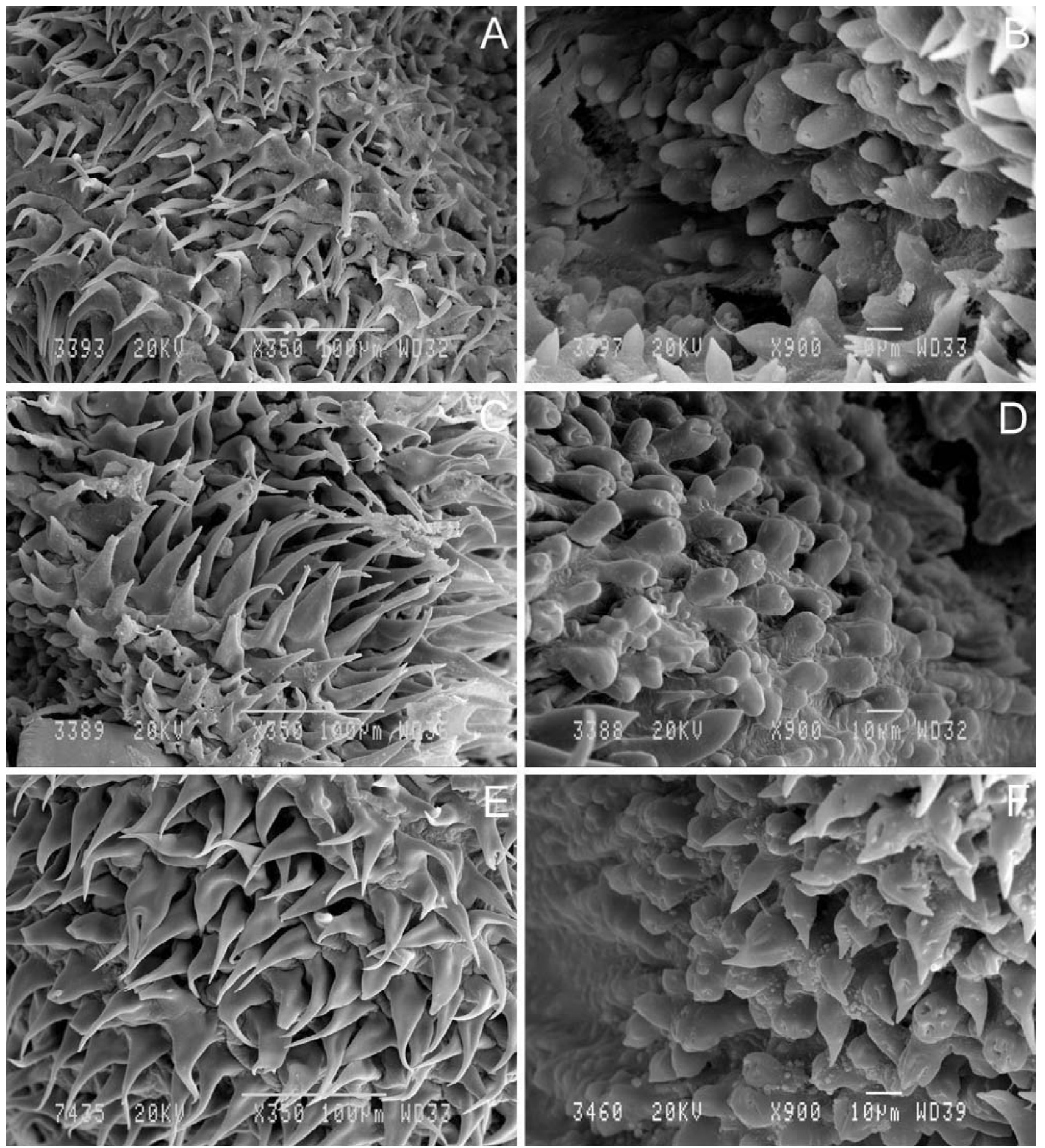

Fig. 7. Puparium of Scaeva (Semiscaeva) spp. (A, C, E - microtrichia on the central area of the posterior fold, dorsal view; B, D, F - integumental vestiture of the depression below PRP). A, B - S. selenitica; C, D - S. mecogramma; E, F - S. dignota.

0.35-0.4 mm, height: $0.20-0.25 \mathrm{~mm}, \mathrm{n}=6$ ). PRP smaller and darker in relation to $S$. selenitica/dignota. Short and dark brown in colour at least in puparium. Median groove slightly less deep than half the length of PRP, tips of the dorsal spurs as wide apart as less than semi-diameter of spiracular plate (Figs 8C, 8D). Ecdysial scars displaced towards median groove and anteriorly (Fig. 8C). Periorificial setae mounted inside of circular nodules, periorificial setae between orificia I and II close, but border of their nodules separated (Fig. 8C).
Material examined. Spain. Valencia, Moncada: 4 puparia $(1 \delta, 3 q)$ leg. as larvae 23.xi.1996, leg. M.J. Verdú; 3 puparia $(2 \widehat{0}, 1$ q ) leg. as larvae 18.vii.1996, leg. M.A. Marcos-García; 1 puparium (ô) 8 larvae, leg. as larvae 23.xii.1996, leg. S. Rojo; Alicante, San Vicente del Raspeig: 3 larvae, leg. as larvae 13.v.1998, leg. J.V. Falcó; 3 puparia $(1 \delta, 2 q)$ leg. as larvae 7.vi.1998, leg. J.V. Falcó.

Distribution. South Europe. 

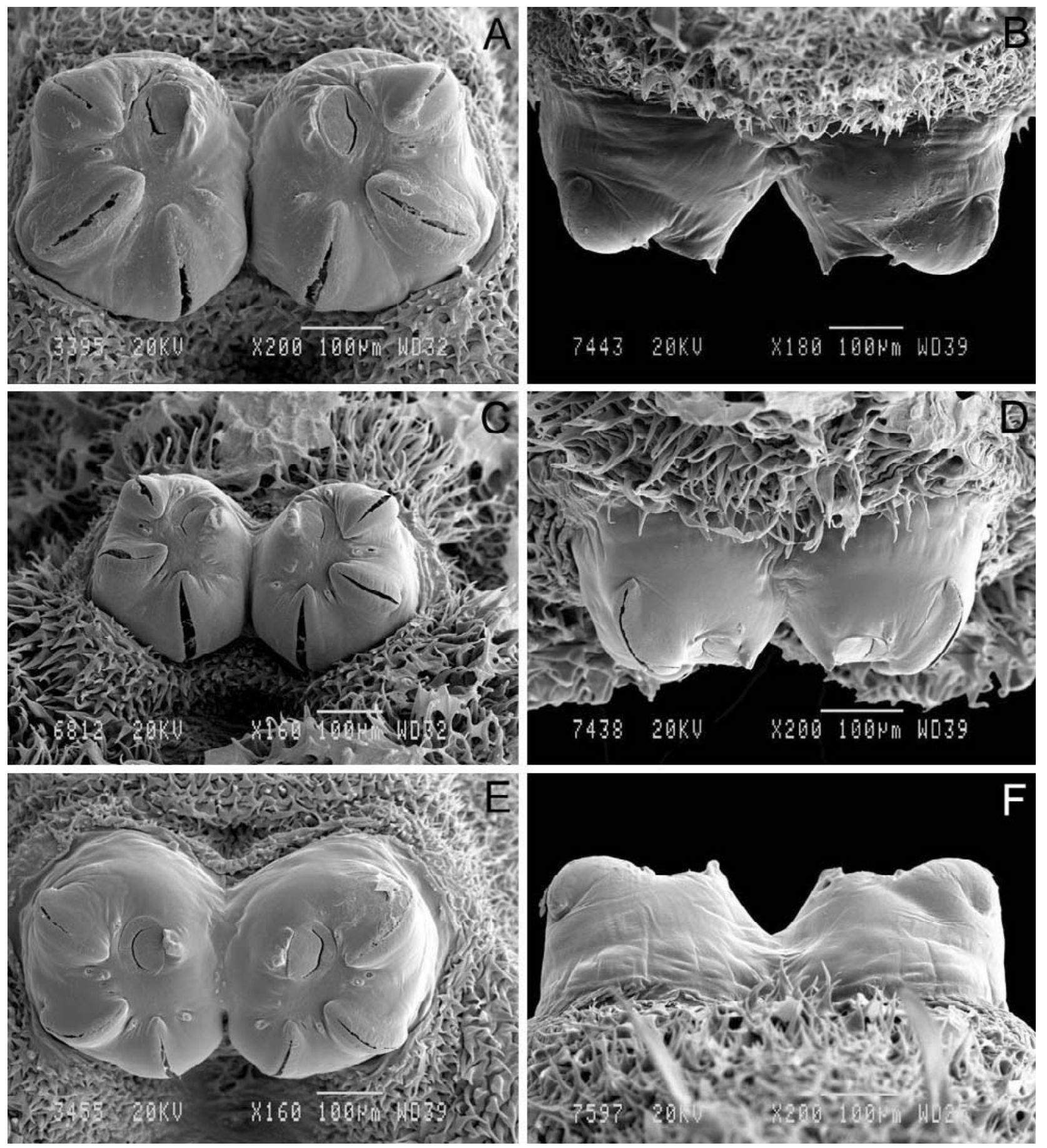

Fig. 8. PRP of puparium of Scaeva (Semiscaeva) spp. (A, C, E - posterodorsal view view; B, D, F - anterodorsal view). A, B - S. selenitica; C, D - S. mecogramma; E-F - S. dignota.

\section{Scaeva dignota (Rondani, 1857)}

Immature stages described here for the first time. Larvae probably predatory on a wide range of aphids. Prey records cited by Dušek \& Láska (1985) and Starý \& Havelka (1991). Prey records from southern part of Europe could be erroneously referred to $S$. selenitica.

Diagnostic characters. Larva and puparium very similar to $S$. selenitica including coloration variability of larvae. Dorsal body surface coated with well developed microtrichia about $0.03-0.045 \mathrm{~mm}$ long, pigmentation of microtrichia less intense than in $S$. selenitica, cuticle of puparium mainly without dark segmental patterns. Posterior folds coated with microtrichia with a wide base that become progressively fine (Fig. 7E). PRP: (Width: $0.45-0.55 \mathrm{~mm}$, height: $0.28-0.36 \mathrm{~mm}, \mathrm{n}=30$; PRP size not affected by parasitation of Diplazon Ness, 1818 (Hymenoptera: Ichneumonidae), contrary to the observation of Dušek et al. (1979), who described the influence of parasitation on PRP size of puparia in Syrphus). Median groove deeper than half the length of PRP, in 

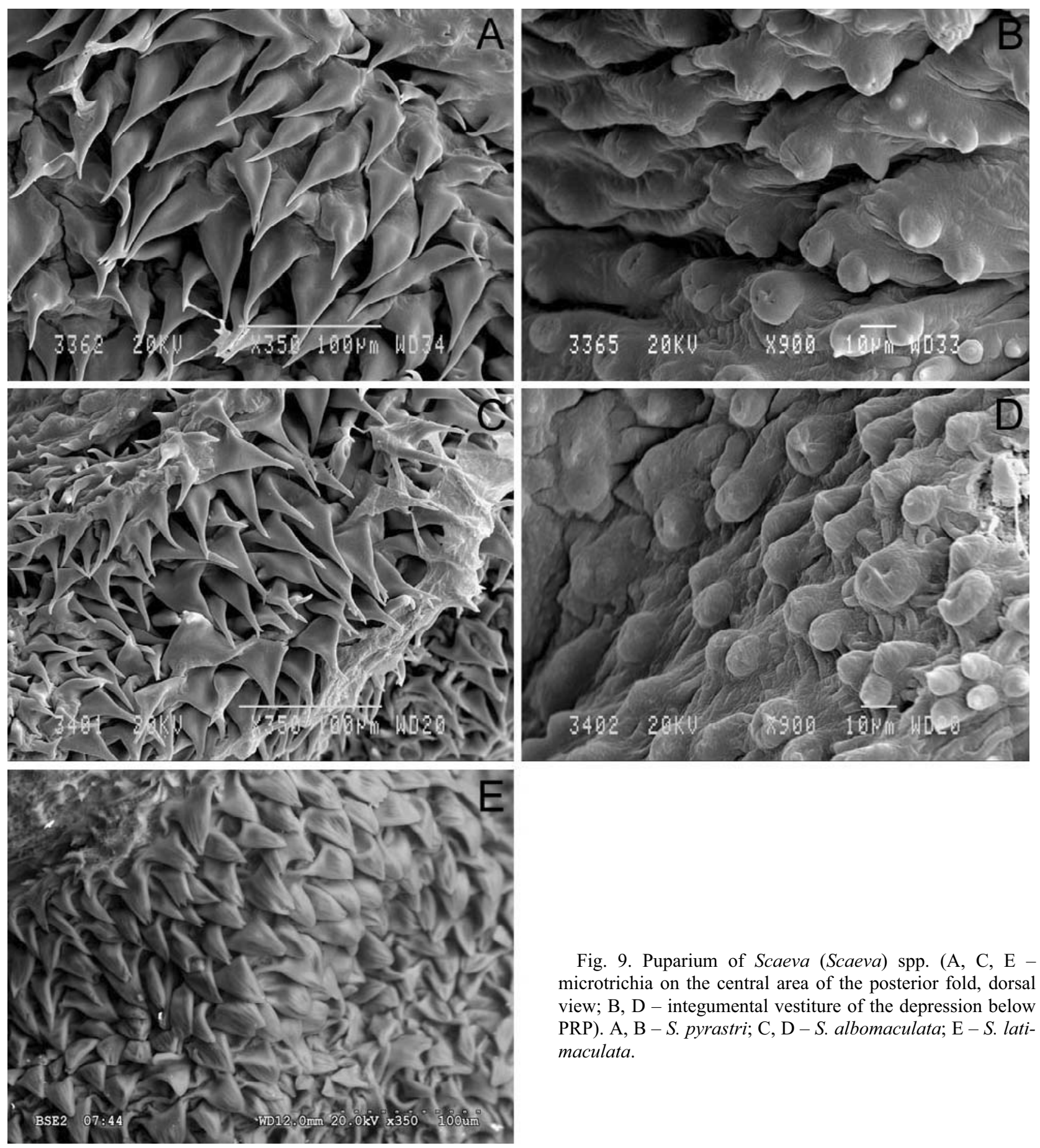

Fig. 9. Puparium of Scaeva (Scaeva) spp. (A, C, E microtrichia on the central area of the posterior fold, dorsal view; B, D - integumental vestiture of the depression below PRP). A, B - S. pyrastri; C, D - S. albomaculata; E - S. latimaculata.

anterior view tips of dorsal spurs as wide apart as more than semi-diameter of a spiracular plate (Figs 8E, F). Ecdysial scars slightly anterior to centre of each spiracular plate (Fig. 8E). Periorificial setae mounted inside of circular nodules, periorificial setae between orificia I and II close, but border of their nodules separated (Fig. 8E).

Material examined. Czech Republic. Žlunice, distr. Jičín: 1 puparium ( $\delta$ numbered G 72), leg. as puparium 23.vi.1959 on the blade of grass in deciduous forest, leg. P. Láska; Olomouc: 1 puparium ( $q$ numbered 5VZ01/1), leg. as larva 21.vi.2001 feeding on Aphis sambuci on Sambucus nigra, leg. M. Štibnarová \& M. Hanáková; 1 puparium (ํ), leg. as larva 10.vi.1994, leg. L. Mazánek. Turkey. İzmir, Karşiyaka: 1 puparium, leg. as larva 19.iv.1976 on aphids colony on Prunus domestica, leg. E. Erkin; İzmir, Urla: 1 dried larva, 24.iv.1975 on aphis colony on Vicia faba, leg. E. Erkin; İzmir, Menemen: 1 puparium, leg. as larva 21.iv.1975 on aphis colony on Prunus communis, leg. E. Erkin. Greece. Lesbos, Mytilene: 3 puparia $(1 \hat{\delta}, 2$ ㅇ $)$ leg. as larvae 10.iii.2001, leg. S. Rojo \& C. PérezBañón; Polihnitos: 9 puparia $(4 \delta, 5 q)$ leg. as larvae, leg. S. Rojo \& C. Pérez-Bañón; Agh. Paraskevi: 10 puparia $(60,4 \%)$ leg. as larvae 27.iii.2001, leg. S. Rojo \& C. Pérez-Bañón. Spain. Alicante. Tibi: 7 puparia (4ô, 2 $q$ ) leg. as larvae 21.v.1993; leg. S. Rojo; Villena: 3 puparia (3 9 ) leg. as larvae 16.iv.1993; leg. S. Rojo; Biar: 2 puparia (2 $q$ ) leg. as larvae 16.iv.1993; leg. S. Rojo.

Distribution. Sub-Mediterranean (see also discussion). 

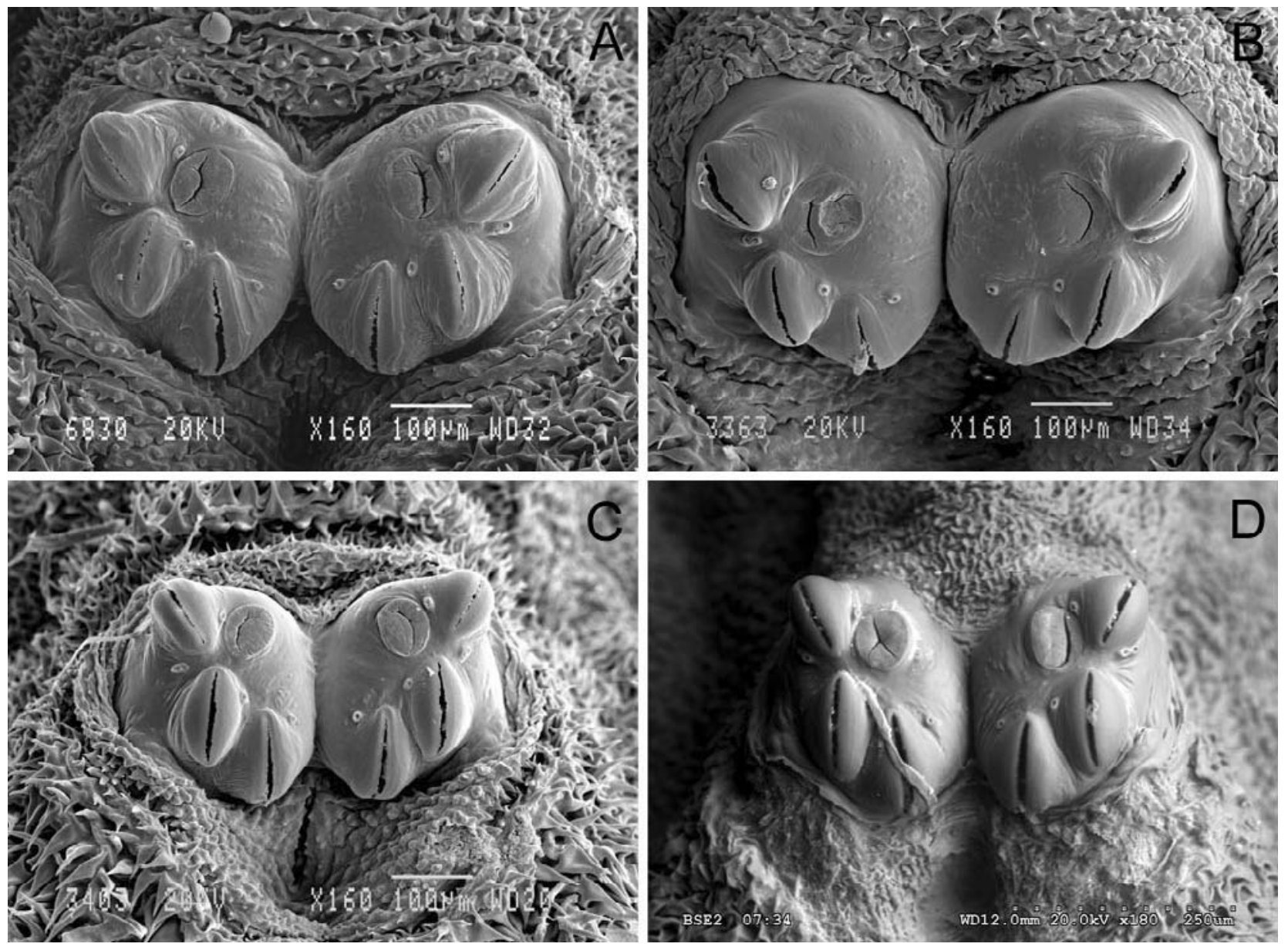

Fig. 10. PRP of puparium of Scaeva (Scaeva) spp., posterodorsal view; A, B - S. pyrastri; C - S. albomaculata; D - S. latimaculata.

\section{Subgenus Scaeva s. str.}

Diagnostic characters. Colour pattern of larva constant, green with white median dorsal stripe. Rarely with pink shade and ochre dorsal stripe. Integument coated with microtrichia, about $0.02-0.035 \mathrm{~mm}$ long on dorsum, that could be reduced to short, almost triangular spicules; microtrichia of cuticle colour or brown pigmented, often furcate especially on folds around PRP. Integument of the depression below PRP covered with smaller, scarcer, slightly pedunculate nodules (Figs 9B, 9D) of whitish colour in puparium. PRP: very short, almost sessile (0.12-0.15 mm long), pale to dark brown in colour. Spiracular plates divided by a $\mathrm{V}$-shape median groove almost as deep as the length of PRP (Fig. 6D). Dorsal spur absent; orificia II and III parallel, orificium III inserted on about $1 / 3$ to nearly $1 / 2$ of length of orificium II posteriorly than orificium II; carinae I and III extending down the sides of PRP; carinae I and II distinctly more developed than carina III (Fig. 6C). Periorificial setae mounted inside of circular nodules; periorificial setae between orificia I and II very close, with border of their nodules connected (Fig. 6C).

\section{Scaeva pyrastri (Linnaeus, 1758)}

Previously described by Martelli (1911), Jones (1922), Krüger (1926), Fluke (1929), Heiss (1938), Bhatia
(1939), Scott (1939), Brauns (1953), Láska (1959), Dušek \& Láska (1959), Dixon (1960), Goeldlin de Tiefenau (1974). Sharma \& Bhalla (1988) dealt with larval biology on laboratory breeding but did not describe immature stages. Barkemeyer (1994) provides a comprehensive literature review of what is known on the biology of this species. Larvae are predatory on a wide range of aphids and also Coccidae, Psyllidae and Thysanoptera; prey records listed by Rojo et al. (2003, p. 192-202).

Diagnostic characters. The last fold anteriorly on PRP rounded, without conical fleshy projection at median point. Segmental spines well developed, about 0.15-0.25 $\mathrm{mm}$ long similar as in the other Scaeva species. Integument on dorsum covered with distinct microtrichia about 0.02-0.035 mm long, of cuticle colour, some of them furcate around PRP. Posterior folds coated with microtrichia with a wide base that becomes progressively fine to apex (Fig. 9A). Puparium usually without brown cuticle segmental patterns and without dried fleshy projections under segmental spines. PRP: (width: 0.5-0.59 mm, height: $0.28-0.36 ; n=10$ ). Almost sessile, lustrous, sclerotized and pale brown in colour. Ecdysial scars slightly anterior to centre of each spiracular plate. Orificia I and II aligned or with angle between them a little less than $180^{\circ}$; orificia II and III almost parallel (Figs 10A, B). 

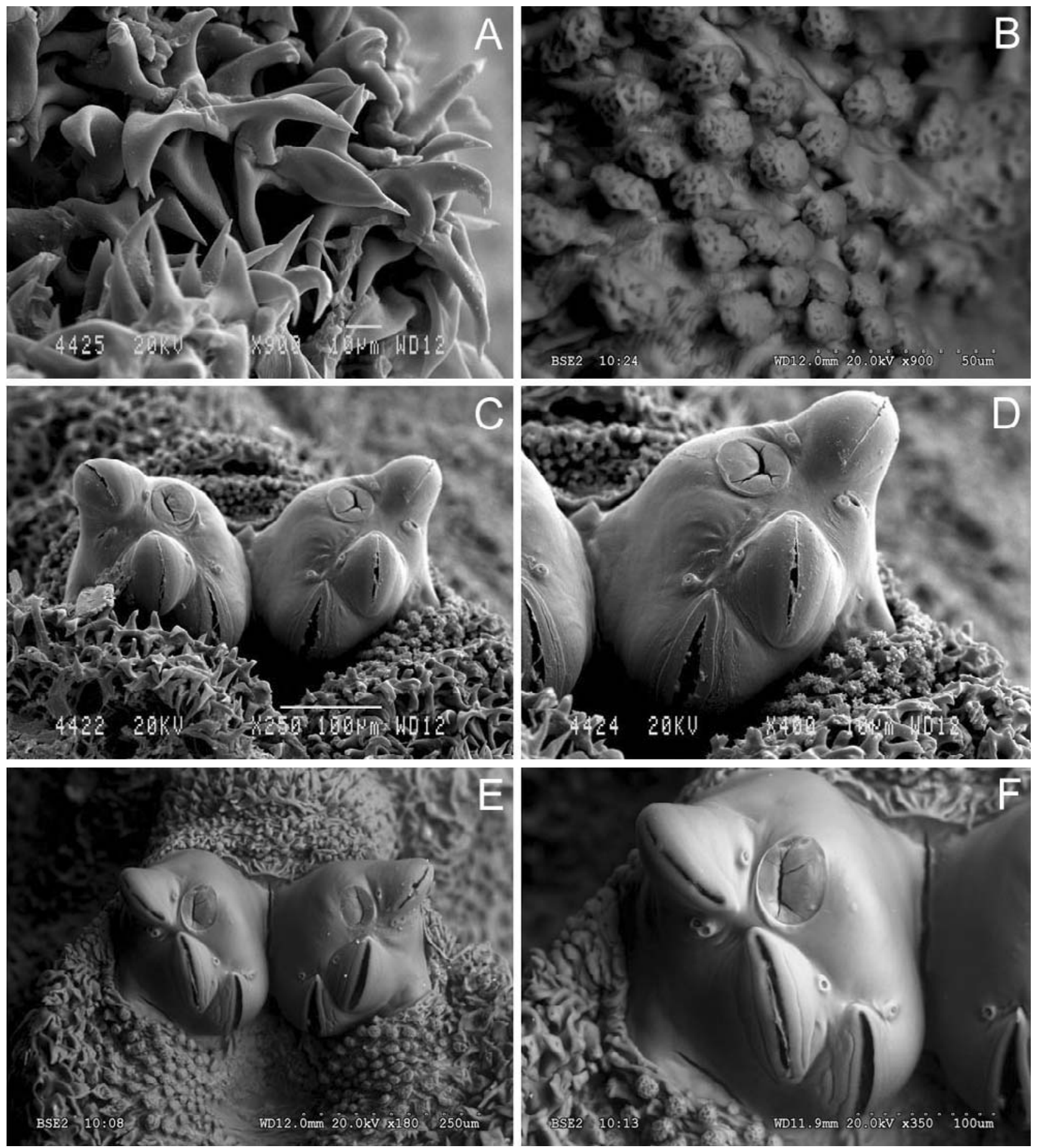

Fig. 11. Puparium of Simosyrphus s. 1. A-D - S. aegyptius: A - microtrichia on the central area of the posterior fold, dorsal view; B - integumental vestiture of the depression below PRP; C - PRP, posterodorsal view; D - spiracular plate, posterodorsal view. E, F - S. grandicornis: E - PRP, posterodorsal view; F - spiracular plate, posterodorsal view.

Material examined. Montenegro. Bečiči near Budva: 9 puparia, leg. as larvae v.1968 feeding on Uroleucon cichorii on Cichorium intybus, leg. P. Láska. Czech Republic. Olomouc: 1 puparium ( $\delta^{\text {) }}$ leg. as larva on aphid colony on Cirsium arvense, 10.vi.1999, leg. L. Mazánek; 53 puparia (240̋, 29 ) 5 lyophilised larvae, 4 larvae in alcohol, reared from eggs, female 14.vi.2001, leg. L. Mazánek; 2 puparia (ô) 1 larva, leg. as larvae 4.vii.2003 feeding on Uroleucon cichorii on Cichorium intybus, leg. L. Mazánek; Mikulčin vrch: 1 puparium (ㅇ) leg. as larva feeding on Uroleucon cichorii on Cichorium intybus, 8.ix.2000, leg. L. Mazánek. Greece. Lesbos, Agh. Parakevi: 1 puparium ( + ) leg. as larvae 27.iii.2001, leg. S. Rojo \& C. PérezBañón; Mistegna: 1 puparium ( + ) leg. as larvae 17.iv.2001, leg. S. Rojo \& C. Pérez-Bañón; Mandamados: 1 puparium (ð) leg. as larvae 18.v.2001, leg. S. Rojo \& C. Pérez-Bañón. Spain. Alicante, San Vicente del Raspeig: 2 puparia (2 $q$ ) leg. as larvae 13.iii.2000, leg, E.S. Ráez; San Vicente del Raspeig: 1 puparium (\$) leg. as larvae 21.iii.2000, leg, E.S. Ráez; San Vicente del Raspeig: 1 puparium (ð) leg. as larvae 28.iii.2000, 
leg, E.S. Ráez; San Vicente del Raspeig: 1 puparium (\$) leg. as larvae 17.xi.2000, leg, E.S. Ráez.

Distribution. Holarctic and marginally Oriental region.

\section{Scaeva albomaculata (Macquart, 1842)}

Previously described by Kuznetzov \& Daminova (1994). Larvae predatory on a wide range of aphids; prey records listed by Rojo et al. (2003, pp. 190-192).

Diagnostic characters. Last fold anterior of PRP enlarged, forming conical fleshy projection at median point (Fig. 1C). Fully developed segmental spines about $0.15-0.25 \mathrm{~mm}$ long. Integument on dorsum covered with distinct microtrichia about $0.02-0.035 \mathrm{~mm}$ long, browned towards top and often furcate on folds around PRP. Posterior folds coated with microtrichia with a wide base becoming progressively fine to apex (Fig. 9C). Puparium usually with tubercle (= rest of dried fleshy conical projection in larva) before PRP (Fig. 1D) and also dried fleshy projection often persist as microtrichose portion under base of some segmental spines on posterior part of puparium. PRP: (width: 0.39-0.44 mm, height: $0.25-0.3$, $\mathrm{n}=5$ ). Almost sessile, lustrous, sclerotized and pale brown in colour. Ecdysial scars displaced towards the median groove and anteriorly; orificia II and III almost parallel (Fig. 10C).

Material examined. Spain. Alicante, San Vicente del Raspeig: 1 lyophilised larva, reared from eggs, female 27.ii.2000, leg. L. Mazánek; Ibi: 6 puparia $(4 \delta, 2 q)$ leg. as larvae 6.vii.1992, leg. S. Rojo; Villena: 3 puparia $(2 \hat{0}, 1$ 우 leg. as larvae 26.vi.1992, leg. S. Rojo; Sax: 1 puparium (ô) leg. as larva 28.vi.1992, leg. S. Rojo; Alcoy: 1 puparium () leg. as larva 21.v.1992, leg. S. Rojo. Italy. Roma, park Glyphinia: 1 puparium (numbered 63/307), leg. as larva 16.vi.1963, leg. P. Starý.

Distribution. South part of Palaearctic to north part of Oriental region.

\section{Scaeva latimaculata (Brunetti, 1923)}

Previously described by Kumar et al. (1987). Several economically important aphid species were cited as prey of this species by Agarwala et al. (1984) and Kumar et al. (1987).

Diagnostic characters. The larva is similar to that of $S$. pyrastri, from which it differs by less developed integumental vestiture, microtichia reduced to short, almost triangular spicules not longer than $0.02 \mathrm{~mm}$, spicules of cuticle colour or browned. Segmental spine shorter than in the other Scaeva species; most developed spines about $0.15 \mathrm{~mm}$ long. Posterior folds coated with longer microtrichia not fine at apex and often furcate (Fig. 9E). Cuticle of puparium with or without darkened segmental patterns, rests of dried fleshy projections absent. PRP: (width: 0.33-0.39 mm, height: $0.21-0.26 \mathrm{~mm}, n=2$ ). Ecdysial scars displaced towards the median groove and anteriorly; orificium I on most developed carina that overlaps anterior margin of spiracular plate in dorsal view; orificia II and III almost parallel (Fig. 10D).

Material examined. India. Punjab: 1 puparium ( $\$$ - SEM photos). leg. as larva, leg. A. Kumar; Himachal Pradesh, 1 puparium ( 9 numbered 104), leg. as larva on Hyperomyzus carduellinus on Emilia sonchi leg. K. Agarwala. Iran. Mahabad 82 km S., $2600 \mathrm{~m}: 1$ puparium (\%) leg. as larva 6.vii.1974 on Papaver sp., leg. C. Buckingham.

Distribution. Southern Palaearctic from Iran eastwards into Oriental region.

\section{Simosyrphus Bigot, 1882}

\section{Third instar larva}

We could not examine the larvae, but according to previous descriptions of Barbosa (1952), Lal \& Gupta (1953), Tawfik et al. (1974), Roy \& Basu (1977), Kumar et al. (1987), Soleyman-Nezhadiyan (pers. com.) and a black and white photo of Schmutterer (1972), the larvae of this genus are very similar to smaller larvae of Scaeva s.str. in overall appearance: (Length including PRP 7-12.5 mm, maximum width $2-3 \mathrm{~mm}$ ) oval in crosssection, relatively high; locomotory prominences well developed; body wrinkled and green coloured with middorsal whitish stripe. Some species have on each side of white stripe a line of spots or narrow stripes orange to light brown coloured and spots or stripes along lateral margins of larvae. These patterns also visible in fleshy projection bearing segmental spines. However, Rotheray \& Gilbert (1999) give some new characters that show the close relation between these two genera: presence of setae on the sensillae $7^{\mathrm{Mt}}, 8^{\mathrm{Mt}}$ and $9^{\mathrm{Mt}}$ (that was confirmed by our study of puparia); the locomotory prominences on $6^{\text {th }}$ and $7^{\text {th }}$ abdominal segments with the tips directed backwards; and an extra lobe on the locomotory prominences of abdominal segments $1-7$.

We can add some new data to this list of characters obtained from the puparium: segmental spines relatively long (about 0.1-0.21 mm long in dorsum, measured in puparium), with the same pattern and arrangement as in the Scaeva species, only fleshy projections bearing segmental spines are more developed. Integument covered by short pointed spicules rather than microtrichia, about 0.02 $\mathrm{mm}$ long, on posterior folds longer and wider and often furcate (Fig. 11A); integument of depression below PRP and also small area close before PRP covered with nodular rounded papillae (Fig. 11B).

PRP: similar to PRP of sg. Scaeva, very short, almost sessile (0.1-0.15 mm long), only width of PRP differs according to species. Spiracular plates higher than wide, divided by a V-shape groove as deep as length of PRP; dorsal spur absent; orificia II and III almost parallel; orificium III inserted more posteriorly than in the Scaeva subgenus, on about half or more of the length of orificium II. Carina I well developed, distinctly overlapping the anterior margin of spiracular plate in dorsal view (Figs $11 \mathrm{C}-\mathrm{F})$. Periorificial ornamentation reduced as in the Scaeva species; periorificial setae very small hardly visible by light microscope, mounted inside of small circular nodules (Figs 11C-F); periorificial setae between orificia I and II very close, with border of their nodules connected.

\section{Puparium}

Length including PRP 5.5-7.0 mm, maximum width 2.5-3.2 mm. Puparia of similar shape as in Scaeva but smaller. Colour varying from cream to dull brown, also at 
intraspecific level. Integumental vestiture persisting, of cuticle colour or a little darkened, rarely forming slightly darkened segmental patterns with pigmented cuticle. Segmental spines elongated by persisting dried fleshy projections that form microtrichose portion under segmental spines, especially on dorsum of posterior part of puparium. Segmental spines of cuticle colour or browner, variable also at intraspecific level. PRP with carinae usually blacked, nodular integument of depression below PRP and also small area close before PRP usually whitish.

\section{Simosyrphus grandicornis (Macquart, 1842)}

Soleyman-Nezhadiyan (1997) and Soleyman-Nezhadiyan \& Laughlin (1998) deal with larval biology of laboratory breedings but do not describe immature stages. Larvae predatory on a wide range of aphids and even lepidopteran larvae; prey records reported by Rojo et al. (2003, pp. 204-205).

Diagnostic characters. Larva green with whitish median stripe (E. Soleyman-Nezhadiyan, pers. com.). Segmental spines relatively short, fully developed only about $0.1-0.14 \mathrm{~mm}$ long, fleshy projections bearing segmental spines less developed, dried persist under several segmental spines on posterior part of dorsum of puparium as microtrichose portion (maximum length $0.05 \mathrm{~mm}$ ). Microtrichia of cuticle colour or slightly dark brown pigmented, especially around segmental spines, but puparium without visible dark coloured pattern. PRP: somewhat smaller than in other species of the genus, about $0.26-0.30 \mathrm{~mm}$ wide and $0.14-0.18 \mathrm{~mm}$ high $(\mathrm{n}=$ 2). Length of PRP about $0.1 \mathrm{~mm}$. Carina I well developed, rounded apically (Fig. 11D).

Material examined. Australia. Nethy Bridghe: 1 puparium ( + ) leg. as larva 11.xi.1974; 1 puparium ( + - SEM photos), reared on Hyperomyzus lachicae, leg. as larva 11.xi.1974; Mosman NSU: 1 puparium (o) reared on Schaitedonia lutea, leg. as larva 18.i.1973. All leg. D. Hales.

Distribution. Australia, Oceania.

\section{Simosyrphus aegyptius (Wiedemann, 1830) comb. $\mathbf{n}$.}

Previously described by Barbosa (1952), Tawfik et al. (1974). Larvae predatory on a wide range of aphids and also on Thysanoptera; prey records cited by Rojo et al. (2003, p. 116-118). Even lepidopterous larvae were cited as preys by Randrianandrianina-Razananaivo (1991).

Diagnostic characters. Larva yellowish green with mid-dorsal white stripe flanked by developing narrow orange or light brown stripes; yellowish orange fat bodies discerned also in fleshy projections forming lateral orange line. As the fat bodies extend, larvae become rather yellowish orange. Fully developed segmental spines about $0.16-0.2 \mathrm{~mm}$ long mounted on well developed fleshy projection that dried persist on puparium under segmental spines as microtrichose portion long almost $0.12 \mathrm{~mm}$, especially on posterior part of dorsum. PRP: about $0.38-0.43 \mathrm{~mm}$ wide and $0.24-0.30 \mathrm{~mm}$ high $(\mathrm{n}=5)$. PRP length about $0.12-0.14 \mathrm{~mm}$. Carina I rather sharp apically (Fig. 11F).

Material examined. Kenya. Nairobi-Chiromo: 4 puparia $(2 \hat{0}, 2 \%)$ reared on Rhopalosiphum maidis, leg. as larvae 22.ii.1970, leg. H. Schmutterer; 2 puparia (\$) reared on Rhopalosiphum maidis, leg. as larvae 20.vi.1970, leg. H. Schmutterer. Senegal. Ziguinchor, Djibélor: 3 puparia $(20$ - SEM photos, 1 \%) leg. as larvae 18.xi.1979 on Toxoptera aurantii, leg. J. Etienne.

Distribution. Afrotropical, including Madagascar, Réunion and South-West Palaearctic (North Africa, Southern Spain, Madeira and Canary Islands).

\section{Simosyrphus scutellaris (Fabricius, 1805) comb. n.}

Immature stages were previously described by Lal \& Gupta (1953), Okuno (1967), Roy \& Basu (1977) and Kumar et al. (1987). Ninomyia (1959) described only the puparium of an aberrant specimen with only two orificia on one of two spiracular plates. Lal \& Haque (1965), Agarwala \& Saha (1986), Sharma \& Bhalla (1988) and Singh \& Mishra (1988) studied biology of immature stages in detail but did not describe the immature stages. Larvae predatory on a wide range of aphids and even lepidoptera larvae; prey records listed by Rojo et al. (2003, p. 118-122).

Diagnostic characters. Larvae green to greenishbrown coloured with mid-dorsal whitish stripe and with reddish to brown fat bodies along mid-dorsal stripe, in fleshy projections and along lateral margin of larvae. Fully developed segmental spines about $0.13-0.18 \mathrm{~mm}$, mounted on well developed fleshy projection that dried persist on puparium under base of segmental spines as microtrichose portion long almost $0.08 \mathrm{~mm}$, especially on posterior part of dorsum. PRP: about $0.43-0.53 \mathrm{~mm}$ wide and $0.26-0.34 \mathrm{~mm}$ high, $(\mathrm{n}=2)$; length about $0.13 \mathrm{~mm}$.

Material examined. India. Punjab: 1 puparium ( $\hat{\sigma})$ leg. as larva, leg. A. Kumar; Agartala: 1 puparium, leg. as larva 1980 on Aphis gossypii on Gossypium sp., leg. K. Agarwala.

Distribution. Southern Palaearctic (from Iran, Turkey to Japan), Oriental region, Australia, Pacific (excl. Hawaiian Is).

\section{KEY FOR THIRD INSTAR LARVAE AND PUPARIA}

1 Angles between adjacent orificia about $90^{\circ}$, dorsal spur present (Figs 6A, B) (sg. Semiscaeva ). . . . . . . . . . . . . 2

- Orificia II and III almost parallel, dorsal spur absent (Figs

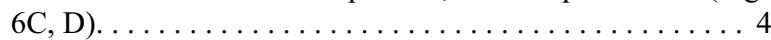

2 Width of PRP about $0.5 \mathrm{~mm}$ or more; median groove deeper than half the length of PRP (Figs 8B, F) . . . . . . . . 3 Width of PRP about $0.4 \mathrm{~mm}$ or less; median groove slightly less deep than half the length of PRP (Fig. 8D). . . . . . . . Scaeva (Semiscaeva) mecogramma

3 Posterior folds coated with microtrichia with a wide base that become suddenly fine (Fig. 7A); some microtrichia of integumental vestiture pigmented apically; puparium usually with distinct dark dotted segmental pattern. . . . . . . . . . . Scaeva (Semiscaeva) selenitica

- Posterior folds coated with microtrichia with a wide base that become progressively fine to the apex (Fig. 7E); body coated with microtrichia of cuticle colour or almost so; puparium without dark dotted segmental pattern. ......... Scaeva (Semiscaeva) dignota

4 Integumental vestiture distinct, microtrichia about $0.2-0.35$ $\mathrm{mm}$ long on dorsum; microtrichia on posterior folds with thin apex (Figs 9A, C); orificia located on high oval carinae, slightly less developed in orificium III (Figs 10A, B, C) . . 5 
TABLE 3. Sequence varibility in the variable regions of the ca $450 \mathrm{nt}$ ITS2 (arbitrary alignment) that were obtained for all of the sequenced $S$. dignota specimens (genotype 1 ) and the $S$. selenitica specimens (genotype 2).

Genotype Sequence varibility in the variable region of the ca $450 \mathrm{nt}$ ITS2

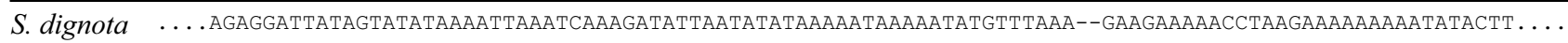

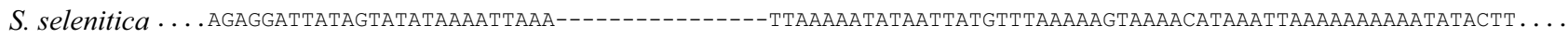

- Integumental vestiture reduced, microtrichia on dorsum about $0.02 \mathrm{~mm}$ long or shorter; microtrichia on posterior folds relatively broad near apex (Figs 9E, 11A); orificia located on very high oval carinae except orificium III located on distinctly less developed carina (10D, 11D, F). 6

5 Fold close to anterior part of PRP forming conical fleshy projection in median point (Fig. 1C), when dried, usually also apparent on puparium as a tubercle overlapping with PRP (Fig. 1D); ecdysial scars displaced towards the median groove and anteriorly (Fig. 10C). . . . . . . . . . . . ..................... Scaeva (Scaeva) albomaculata Fold close to anterior part of PRP regularly rounded lateromedially without conical fleshy projection; ecdysial scars slightly anterior to centre of each spiracular plate (Figs 10A, B). . . . . . . . . . . . . . Scaeva (Scaeva) pyrastri

6 Orificium III inserted only about $1 / 3$ the length of orificium II posteriorly to orificium II; carina III distinct and carina I about as developed as carina II (Fig. 10D); fleshy projection under segmental spines less developed, not persist on puparium, so that segmental spines are sessile on puparium. ..... ..................... Scaeva (Scaeva) latimaculata Orificium III inserted about half or more the length of orificium II posteriorly to orificium II; carina III almost flat and carina I enlarged, distinctly overlapping periphery of PRP (Figs 11D, F); fleshy projection under segmental spines more prominent, dried persist as microtrichose portion under segmental spines on puparium, especially on posterior part of dorsum (g. Simosyrphus) . . . . . . . . . . . . 7

7 Width of PRP about $0.3 \mathrm{~mm}$ or less; the most developed segmental spines about $0.1-0.14 \mathrm{~mm}$ long, in puparium elongated by microtrichose rests of dried fleshy projections nearly to $0.18 \mathrm{~mm}$, especially on posterior part of dorsum...
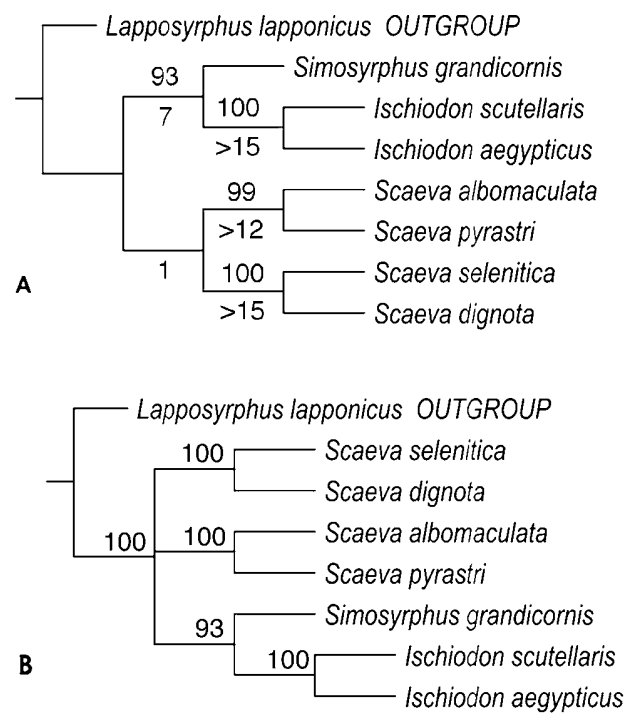

Fig. 12. A - Most parsimonious tree obtained using Nona for $1128 \mathrm{bp}$ of the $\operatorname{coxl}$ gene, length $=224$ steps, $\mathrm{CI}=0.83$, RI $=$ 0.74. Bootstrap support values and Bremer support (branch support) values are reported above and below nodes, respectively. B - Parsimony jackknifing tree (1000 replicates). $\ldots \ldots \ldots \ldots \ldots$ Simosyrphus grandicornis PRP wider than $0.35 \mathrm{~mm}$; segmental spines longer, fully developed about $0.13-0.2 \mathrm{~mm}$ long, in puparium elongated by microtrichose rests of dried fleshy projections to about $0.2-0.3 \mathrm{~mm}$, especially on posterior part of dorsum.... 8

8 Width of PRP about $0.38-0.43 \mathrm{~mm}$; fully developed segmental spines about $0.16-0.2 \mathrm{~mm}$ long, in puparium elongated by microtrichose rests of dried fleshy projection to about $0.3 \mathrm{~mm}$, especially on posterior part of dorsum...... ................... Simosyrphus aegyptius comb. n.

- Width of PRP about $0.43-0.53 \mathrm{~mm}$ or longer; fully developed segmental spines about $0.13-0.18 \mathrm{~mm}$ long, in puparium elongated by microtrichose rests of dried fleshy projection nearly to $0.24 \mathrm{~mm}$, especially on posterior part of dorsum. ............ Simosyrphus scutellaris comb. n.

\section{MOLECULAR STUDIES}

The parsimony analysis of 1128 nucleotides of the cox 1 gene of seven taxa belonging to Scaeva and Simosyrphus, using Eupeodes (Lapposyrphus) lapponicus as outgroup, produced one most parsimonious tree (Fig. 12A) of 224 steps $(\mathrm{CI}=0.83 ; \mathrm{RI}=0.74)$. All proposed subgeneric and generic taxa based on morphological studies receive high bootstrap support (1000 replicates). We did not recover a closer relationship of sg. Scaeva with Simosyrphus than with sg. Semiscaeva, even if this node is suggested from the immature morphology (see Discussion). Resampling using jackknifing spawn from Winclada is shown in Fig. $12 \mathrm{~B}$

Coxl sequences of Scaeva selenitica and S. dignota were identical except for one nucleotide change in one $S$. dignota specimen. The six specimens of $S$. dignota presented identical ITS2 sequences (genotype 1, Table 3) and the five specimens of $S$. selenitica were also monomorphic for ITS2 (genotype 2). These two genotypes are distinct.

\section{DISCUSSION}

\section{Taxonomy of Scaeva}

According to our results, the Palaearctic Scaeva species can be split into two groups based on the analysis of immature stages. One group $(S$. dignota, $S$. selenitica, $S$. mecogramma) has a distinct angle of about $90^{\circ}$ between orificia II and III, as is typical for other related genera of Syrphini. A second group ( $S$. pyrastri, S. albomaculata, $S$. latimaculata) has the orificia II and III (on spiracular plate) parallel, with insertion of orificium III beneath the level of insertion of orificium II (probably apomorphic situation). These two groups that should be classified as subgenera were designated as natural groups within Scaeva by Dušek \& Láska (1985) (S. selenitica-group vs S. pyrastri-group). Independently, Kuznetzov (1985) divided the Palaearctic Scaeva species in three subgenera based exclusively on adult morphology (Semiscaeva 
Kuznetzov, 1985: 412, Mecoscaeva Kuznetzov, 1985: 418 and Scaeva s. str.). However, his arrangement of the species does not agree with the results of the present paper. The main differences are that following this author the species $S$. mecogramma (type species of subgen. Mecoscaeva), $S$. dignota (junior syn. of which is the type species of his subgen. Semiscaeva) and S. selenitica (from his subgen. Scaeva) are closely related on the basis of pre-imaginal and molecular data. According to our results they form a natural group that is identical to S. seleniticagroup (sensu Dušek \& Láska, 1985). The name Semiscaeva Kuznetzov, 1985 should be the valid name for the S. selenitica-group (sensu Dušek \& Láska, 1985) as a subgenus of the genus Scaeva. The subgenus Scaeva s. str. can only be referred to the $S$. pyrastri-group (sensu Dušek \& Láska, 1985) and as the first revisers we determine subgen. Mecoscaeva Kuznetzov, 1985 syn. n. as a junior synonym of subgen. Semiscaeva Kuznetzov, 1985.

\section{Status of Scaeva dignota and S. selenitica}

Scaeva dignota was recognized (from variability of $S$. selenitica) as a valid species by Dušek \& Láska (1985). These authors observed that the anterior angle of approximation of eyes in males of $S$. dignota is narrow $\left(90^{\circ}-\right.$ $106^{\circ}$ ), face is narrower and ocular hairs are shorter in comparison with $S$. selenitica. The pattern of yellow spots on tergites 3 and 4 differs a little between the species. However, except for size differences of microtrichia of the posterior fold, we have been unable to found informative characters to distinguish larvae or pupae of these species. Moreover, these species present dichroism of larvae (green vs brown colour). We have observed this peculiar phenomenon only in these two species of the genus Scaeva. Male terminalia in both taxa are very similar. $S$. dignota is mainly a Mediterranean species and $S$. selenitica is a sub-boreal species (Dušek \& Láska, 1985). The molecular analysis also indicated a very close relationship between these species, as both taxa presented identical coxl sequences in all the studied material (Czech, Spanish, Finnish and Greek specimens). This clearly supports that a separation of these two closely related species into different subgenera as done by Kuznetzov (1985) is unfounded. However, the nuclear ITS2 region sequenced for several $S$. dignota and $S$. selenitica from central Europe presented two different genotypes (Table 3). The utility of the mitochondrial cox 1 gene is limited when addressing questions about species delimitation between very closely related species, but the ITS2 proved to be informative even for these cases. The identical mitochondrial coxl sequences and divergent nuclear ITS2 could demonstrate a case of mitochondrial introgression between $S$. selenitica and $S$. dignota. The geographical distributions of both taxa overlap in the Central European Alps and warmer parts of Palaearctic (particularly Mediterranean).

\section{Taxonomy of Simosyrphus}

Vockeroth (1969) stated the close relation of Ischiodon scutellaris, I. aegyptius and Simosyrphus grandicornis. He mentioned several adult synapomorphies for the three species: similar habitus, colour pattern, a similar shape of head and a reduced antennal pedicel but elongated basoflagellomere. According to our new data, larval and pupal morphology also support the close relationship of these genera. The comparison of puparia of Ischiodon species with the puparium of Simosyrphus grandicornis reveals that the posterior respiratory process, as well as the whole puparium, are almost identical. The syrphid male terminalia are generally good indicators of relationships, but not in all cases. For example, Eupeodes volucris Osten Sacken, 1877, with enlarged and specialised genitalia, is now classified with the species from the previous genus Metasyrphus Matsumura, 1917 in a single genus (Vockeroth, 1986). Similarly, as in the case of E. volucris, we prefer uniting all known species of Ischiodon with Simosyrphus grandicornis considering the identical larval characters, even if $S$. grandicornis differs in the complicated and enlarged male terminalia. According to the results of this study we propose the generic name Ischiodon Sack, 1913 syn. n. as a junior synonym of the genus Simosyrphus Bigot, 1882.

\section{CONCLUSIONS}

The close relationship between Simosyrphus/Ischiodon, Scaeva and Eupeodes was established by Dušek \& Láska (1985: p. 211) based on the special pattern of wing membrane and distinct morphology of larval PRP. Rotheray \& Gilbert (1999) also showed the relationship of Ischiodon + Eupeodes + Scaeva. The character possessed by these three taxa is the presence of setae accompanying ventral sensillae of metathorax in larvae. We have found support for this feature with the additional taxa. However, there is a paradox: the PRP of Scaeva s. str. is more similar to that of Simosyrphus s. 1. than to PRP of Semiscaeva. The general similarity in structure of PRP looks like a clear synapomorphy. This fact is supported also by the morphology of Scaeva (Scaeva) latimaculata, with similar thoracic coloration in adults and similar reduced integumental vestiture of larvae compared with Simosyrphus species. However, adult morphology of Palaearctic Scaeva s. 1. species and Simosyrphus species is very different (including male terminalia). It could indicate that Simosyrphus had not long common evolution with most of the species of Scaeva s. str. Our molecular results do not resolve the relationship between Palaearctic Scaeva s. 1. and Simosyrphus.

Finally, the placement of the Neotropical species referred to genus Scaeva is not resolved here. They form a separate monophyletic group (see Dušek \& Láska, 1985: p. 226) that is probably sister to all Palaearctic Scaeva and Simosyrphus species according to the pattern of wing venation and other characters. They should be classified as a separated taxon (Mazánek \& Láska, in prep.). The phylogenetic relationships of Scaeva and related genera will be reviewed in a further paper.

ACKNOWLEDGEMENTS. Special thanks to D. Hales (Australia) for rearing specially for us the puparia of Simosyrphus grandicornis, to H. Schmutterer (Giessen, Germany), A. Kumar (Ludhiana, India), B.K. Agarwala (Agartala, India) and E. Erkin 
(Izmir, Turkey) who generously donated puparia in their care, to M. Hanáková and M. Štibnarová (Olomouc, Czech Republic) for their help with laboratory breedings and to E. SoleymanNezhadiyan (Ahwaz, Iran) for valuable information about larvae of $S$. grandicornis. We are greatly indebted to T. Petanidou (Greece) for the facilities to study material from Lesbos Island. Financial support was provided by the Spanish Ministry of Environment (040/2002) (C. P-B., M-G.), University of Alicante, Spain (GRE04-25) (C. P-B., S.R) and from Finnish Ministry of Environment (G.S.).

\section{REFERENCES}

Agarwala B.K. \& SaHa J.L. 1986: Larval voracity, development and relative abundance of predators of Aphis gossypii on cotton in India. Series Entomol. (Dordrecht) 35: 339-344.

Agarwala B.K., LÁska P. \& Raychaudhuri D.N. 1984: Prey records of aphidophagous syrphid flies from India (Diptera, Syrphidae). Acta Entomol. Bohemoslov. 81: 15-21.

Álvarez J.A. \& Hoy M.A. 2002: Evaluation of the ribosomal ITS2 DNA sequences in separating closely related populations of the parasitoid Ageniaspis (Hymenoptera: Encyrtidae). Ann. Entomol. Soc. Am. 95: 250-256.

Barbosa A.J. DA S. 1952: Ischiodon aegyptium Wied. (Syrphidae, Diptera): Notas breves sobre a sna biologia e o seu valor no control biológio dos Afídeos do algodoeiro. Rev. Fac. Cienc. Univ. Lisboa (2C) 2: 317-332.

BARKEMEYER W. 1994: Untersuchung zum Vorkommen der Schwebfliegen in Niedersachsen und Bremen (Diptera: Syrphidae). Naturschutz Landschaft. Niedersachs. 31: 1-514.

BeEBe N.W. \& SAUL A. 1995: Discrimination of all members of the Anopheles punctulatus complex by polymerase chain reaction-restriction fragment length polymorphism analysis. Am. J. Trop. Med. Hyg. 53: 478-481.

Bhatia M.L. 1939: Biology, morphology and anatomy of aphidophagous syrphid larvae. Parasitology 31: 78-129.

Bigot J.M.F. 1882: Diagnoses de genres et espèces inédits de Syrphides. (4-ème et dernière partie). Annls Soc. Entomol. Fr. (Ser. 6) 2: 136.

BRAUNS A. 1953: Beiträge zur Ökologie und wirtschaftlichen Bedeutung der aphidivoren Syrphidenarten (Diptera). Ber. Entomol. 3: 278-303.

Bremer K. 1994: Branch support and tree stability. Cladistics 10: $295-304$.

BRYAN E.H. 1934: A review of the Hawaiian Diptera, with descriptions of new species. Proc. Hawaii Entomol. Soc. 8: 399-468.

Caterino M.S. \& Sperling F.A.H. 1999. Papilio phylogeny based on mitochondrial cytochrome oxidase I and II genes. Mol. Phylogen. Evol. 11: 122-137.

CurTis J. 1834: British Entomology; Being Illustrations and Descriptions of the Genera of Insects Found in Great Britain and Ireland. Vol. 11. J. Curtis, London, pl. 509.

Dixon T.J. 1960: Key to and descriptions of the third instar larvae of some species of Syrphidae (Diptera) occurring in Britain. Trans. R. Soc. Entomol. Lond. 112: 345-379.

DušEK J. \& LÁsKA P. 1959: Beitrag zur Kenntnis einiger unbekannter aphidophager Syrphiden-Larven (Diptera, Syrphidae). Acta Soc. Entomol. Cechoslov. 56: 279-292.

DušEK J. \& LÁsKA P. 1964: A contribution to distinguishing the European species of the subgenus Syrphus Fabricius (Diptera, Syrphidae) according to male genitalia and larvae. Acta Soc. Entomol. Čechoslov. 61: 58-70.

DušEK J. \& LÁsKa P. 1985: A review of the genus Scaeva Fabricius (Diptera, Syrphidae) with the description of a new species from Chile. Acta Entomol. Bohemoslov. 82: 206-228.
Dušek J., LÁsKa P. \& ŠEDIVÝ J. 1979: Parasitization of aphidophagous Syrphidae (Diptera) by Ichneumonidae (Hymenoptera) in the Palaearctic region. Acta Entomol. Bohemoslov. 76: 366-378.

EkuKole G. \& AJayi O. 1995: Some observations on Scymnus (Scymnus) floralis (F.) and Ischiodon aegyptius (Wiedemann), predators of the cotton aphid in North Cameroon. J. Afr. Zool. 109: 93-97.

FABRICIUS J.C. 1805: Systema antliatorum secundum ordines, genera, species adiectis synonymis, locis, observationibus, descriptionibus. Brunsvigae (= Brunswick), XIv+15-372+30.

FlUKE C.L. 1929: The known predaceous and parasites of the pea aphid in North America. Res. Bull. Agric. Exp. Sta. Univ. Wisc. 93: 1-47.

Goeldlin de Tiefenau P. 1974: Contributión à l'étude systematique et écologique des Syrphidae (Dipt.) de la Suisse occidentale. Mitt. Schweiz. Entomol. Ges. 47: 151-252.

Goloboff P.A. 1993: NONA, version 2.0 (32 bit version). Program and documentation. Computer program distributed by J. M. Carpenter, American Museum of Natural History, New York.

HARTLEY J.C. 1963: The cephalopharyngeal apparatus of syrphid larvae and its relationship to other Diptera. Proc. Zool. Soc. Lond. 33: 81-87.

Hebert D.N.P., Cywinska A., Ball S.L. \& De WaArd J.R. 2003: Biological identifications through DNA barcodes. Proc. R. Soc. Lond. (B) 270: 313-321.

HeIss E.H. 1938: A classification of the larvae and puparia of the Syrphidae of Illinois exclusive of aquatic forms. Univ. Illinois Bull. 36(1), Illinois Biol. Monograph 16(4), University of Illinois, Urbana, $142 \mathrm{pp}$.

Hull F.M. 1949: The morphology and inter-relationship of the genera of Syrphid flies, recent and fossil. Trans. Zool. Soc. Lond. 26: 257-408.

JoNES C.R. 1922: A contribution to our knowledge of the Syrphidae of Colorado. Bull. Colorado Agric. Exp. Sta. 269: $1-72$.

KASSEBEeR C.F. 1999: The neotropical species of the genus Scaeva Fabricius, 1805 (Diptera, Syrphidae). Dipteron 2: 93-108.

KRÜGER F. 1926: Biologie und Morphologie einiger Syrphidenlarven. Z. Morph. Oekol. Tiere 6: 83-149.

Kumar A., Kapoor V.C. \& LÁsKa P. 1987: Immature stages of some aphidophagous syrphid flies of India (Insecta, Diptera, Syrphidae). Zool. Scripta 16(1): 83-88.

KuZNETZOv S.Y. 1985: Hoverflies of the genus Scaeva Fabricius (Diptera, Syrphidae) of the Palaearctic fauna. Entomol. Obozr. (Rev. Entomol. URSS) 64(2): 398-418. [In Russian, English translation: Entomol. Rev. Washington 64(4): 67-87.]

Kuznetzov S.Y. \& Daminova D. 1994: A description of the puparium of Scaeva albomaculata Mcq. (Diptera, Syrphidae). Dipt. Res. (Riga) 5: 101-104.

LAL R. \& GUPTA S.B.L. 1953: Morphology of the immature stages of Sphaerophoria scutellaris (Fabr.) - (Syrphidae) with notes on its biology. Indian J. Entomol. 15: 207-218.

LAL R. \& Haque E. 1965: Effect of nutrition under controlled conditions of temperature and humidity on longevity and fecundity of Sphaerophoria scutellaris (Fab.) (Syrphidae: Diptera) - Efficacy of its maggots as aphid predators. Indian $J$. Entomol. 17: 317-325.

LÁSKA P. 1959: Příspěvky k poznání aphidofágních pestřenek, zvláště k potravní ekologii larev (Syrphidae, Diptera). [Contributions to the knowledge of aphidophagous hoverflies, especially to the food ecology of larvae.] Bohem. Central. (A) 1: 321-344 [in Czech, English abstr.]. 
LÁSKA P. 1984: A method of comparing the role of aphid parasitoids and predators exemplified by the cabbage aphid, Brevicoryne brassicae. Acta Entomol. Bohemoslov. 81: 81-89.

Martelli G. 1911: Notizie sull Aphis brassicae L. e su alcuni suoi parassiti ed iperparassiti. Portici Boll. Lab. Zool. 5: $40-54$.

Megens H.-J., Van Moorsel C.H.M., Piel W.H., Pierce N.E. \& DE Jong R. 2004: Tempo of speciation in a butterfly genus from the Southeast Asian tropics, inferred from mitochondrial and nuclear DNA sequence data. Mol. Phylogen. Evol. 31: $1181-1196$.

Milankov V., Stamenković J., Ludoški J., StÅhls G. \& Vujić A. 2005: Diagnostic molecular markers and the genetic relationships among three species of the Cheilosia canicularis group (Diptera: Syrphidae). Eur. J. Entomol. 102: 125-131.

Mukhitdinov M. 1985: [Influence of defoliation on larval dynamics of syrphid flies in cotton agrobiocoenosis]. Izv. Akad. Nauk Tadzhikskoi SSR Otd. Biol. Nauk 1985(2): 79-81 [in Russian].

NinOMYia E. 1959: Further notes on the immature stages of aphidophagous syrphid flies of Japan. Sci. Bull. Fac. Lib. Arts Educ. Nagasaki Univ. 10: 23-52.

Nixon K.C. 2002: WinClada ver. 1.00.08. Published by the author, Ithaca, New York.

OKuno T. 1967: On the syrphid larvae attacking the aphids in Japan (Diptera). Mushi. Fukuoka 41(10): 123-141.

Pérez-Bañón C., Rojo S., StÅhls G. \& Marcos-García M.A. 2003: Taxonomy of European Eristalinus (Diptera: Syrphidae) based on larval morphology and molecular data. Eur. J. Entomol. 100: 417-428.

RandRianandRianina-Razananaivo L. 1991: Parasitoids of Spodoptera littoralis Boisduval (Lep. Noctuidae) on cotton in Madagascar. Redia 74: 245-248.

Rojo S., Pérez-Bañón C. \& Marcos-García M.A. 1999: First observations on the biology of Scaeva mecogramma (Bigot, 1860) (Diptera, Syrphidae) and notes on some other syrphids preying on psyllids (Hemiptera, Aphalaridae and Triozidae). Volucella 4: 105-111.

Rojo S., Gilbert F.S., Marcos-García M.A., Nieto J.M. \& MIER M.P. 2003: A World Review of Predatory Hoverflies (Diptera, Syrphidae: Syrphinae) and their Prey. Cibio, Alicante, 319 pp.

Rojo S., Stâhls G., Pérez-Bañón C. \& Marcos-García M.A. 2006: Testing molecular barcodes: Invariant mitochondrial DNA sequences vs the larval and adult morphology of West Palaearctic Pandasyopthalmus species (Diptera: Syrphidae: Paragini). Eur. J. Entomol. 103: 443-458.

Rotheray G.E. 1991: Larval stages of 17 rare poorly known British hoverflies (Diptera: Syrphidae). J. Nat. Hist. 25: 945-969.

Rotheray G.E. \& Gilbert F. 1999: Phylogeny of Palaeartic Syrphidae (Diptera): evidence from larval stages. Zool. J. Linn. Soc. 127: 1-112.

RoY P. \& BASU S.K. 1977: Bionomics of aphidophagous syrphid flies. Indian J. Entomol. (New Delhi) 39: 165-174.

SACK P. 1913: H. Sauter's Formosa-Ausbeute. Syrphiden I. (Dipt.). Entomol. Mitt. 2(1): 1-10.

SCHMUTTERER H. 1972: Zur Beutespezifität polyphager, räuberischer Syrphiden Ostafrikas. Z. Angew. Entomol. 71: 278-286.

ScotT E.I. 1939: An account of the development of some aphidophagous Syrphidae (Dipt.) and their parasites (Hymenopt.). Ann. Appl. Biol. 26: 509-532.

Sharma K.C. \& Bhalla O.P. 1988: Biology of six syrphid predators of cabbage aphid (Brevicoryne brassicae) on seed crop of cauliflower (Brassica oleracea var. botrytis). Indian J. Agric. Sci. 58: 652-654.

Sharma K.C. \& Bhalla O.P. 1991: Predatory potential of syrphid species on different aphids of cruciferous crops in the Mid Hill Regions of Himachal Pradesh. Indian J. Plant Prot. 19: $73-75$

Simon C., Frati F., Beckenback A., Crespi B., Liu H. \& Flook P. 1994: Evolution, weighting, and phylogenetic utility of mitochondrial gene sequences and a compilation of conserved PCR primers. Ann. Entomol. Soc. Am. 87: 651-701.

Singh R. \& Mishra S. 1988: Development of a syrphid fly, Ischiodon scutellaris (Fabricius) on Rhopalosiphum maidis (Fitch). J. Aphidology 2(1-2): 28-34.

Soleyman-Nezhadiyan E. 1997: The Ecology of Melangyna viridiceps and S. grandicornis (Diptera: Syrphidae) and their Impact on Populations of the Rose Aphid, Macrosiphum rosae. $\mathrm{PhD}$ thesis, University of Adelaide, Adelaide, $254 \mathrm{pp}$.

Soleyman-Nezhadiyan E. \& Laughlin R. 1998: Voracity of larvae, rate of development in eggs, larvae and pupae, and flight seasons of adults of the hoverflies Melangyna viridiceps Macquart and Simosyrphus grandicornis Macquart (Diptera: Syrphidae). Aust. J. Entomol. 37: 243-248.

Sörensen J.T., Campbell B.C., Gill R.J. \& Steffen-Campbell J.D. 1995: Non-monophyly of Auchenorrhyncha ("Homoptera"), based upon 18S rDNA phylogeny: eco-evolutionary and cladistic implications within pre-Heteropterodea Hemiptera (s. 1.) and a proposal for new monophyletic suborders. Pan-Pac. Entomol. 71: 31-60.

Speight M.C.D. 2003: Species accounts of European Syrphidae (Diptera) 2003. In Speight M.C.D., Castella E., Sarthou J.-P. \& Ball S. (eds): Syrph the Net, the Database of European Syrphidae. Vol. 39. Syrph the Net publications, Dublin, 209 pp.

Speight M.C.D., De Courcy Williams M. \& Legrand J. 1986: Scaeva dignota and S. mecogramma new to France, with a key for determining species of the genus (Diptera: Syrphidae). Entomologiste 42: 359-364.

StÅnls G. \& Nyblom K. 2000: Phylogenetic analysis of the genus Cheilosia (Diptera, Syrphidae) using mitochondrial COI sequence data. Mol. Phylogen. Evol. 15: 235-241.

Starý P. \& HavelKa J. 1991: Macrosiphum albifrons Essig, an invasive lupin aphid and its natural-enemey complex in Czechoslovakia (Homoptera, Aphididae). Acta Entomol. Bohemoslov. 88: 111-120.

Tawfik M.F.S., Azab A.K. \& Awadallah K.T. 1974: Studies on the life-history and description of the immature forms of the Egyptian aphidophagous syrphids. III. Xanthogramma aegyptium Wied. Bull. Entomol. Soc. Egypt 58: 73-83.

Thompson F.C. 2003: Syrphidae. Biosystematic Database of World Diptera (BDWD). http://www.sel.barc.usda.gov/ names. July 2003.

VIMMER A. 1925: Larvy a kukly dvojkřidlého hmyzu středoevropského se zvláštním žretelem na škůdce rostlin kulturnich. [Larvae and Pupae of Central-European Diptera with Special Reference to Pests of Cultivated Plants]. Prague, 379 pp. [in Czech].

VOCKEROTH J.R. 1969: A revision of the genera of the Syrphini (Diptera: Syrphidae). Mem. Entomol. Soc. Canada 62: 1-176.

VocкеRотн J.R. 1986: Nomenclatural notes on nearctic Eupeodes (including Metasyrphus) and Dasysyrphus (Diptera, Syrphidae). Can. Entomol. 118: 199-204.

Xiong H. \& Dong H. 1991: The oviposition behaviour of Scaeva pyrastri (Hym.: Syrphidae) and its control effect on aphids in greenhouses. Chinese J. Biol. Control 7(2): 49-52.

Received February 1, 2005; revised and accepted January 30, 2006 